VOLUME 3 NOMOR 2 JUNI 2020

PERAN STAIN SORONG TERHADAP PENGEMBANGAN KETERAMPILAN BAHASA INGGRIS DI PAPUA BARAT

Bunyamin

STRATEGI PONDOK PESANTREN DALAM MENGHADAPI TANTANGAN GLOBALISASI (STUDI KASUS DI PONDOK PESANTREN API ASRI TEGALREJO MAGELANG)

Ayu Suci Rianingsih, Hairiyah

REKOGNISI KEBIJAKAN PEMERINTAH TERHADAP PESANTREN SEBAGAI LEMBAGA PENDIDIKAN DI INDONESIA

Muh. Mustakim

KONSEP KEPEMIMPINAN DALAM PERSPEKTIF TEOLOGI SYIAH

Kamaluddin Nurdin Marjuni

ISLAMISASI ILMU DALAM KONTEKS PENDIDIKAN ISLAM KONTEMPORER DI INDONESIA

Laelatul Badriah dan Ahmad Syamsul Arifin

ISLAMISASI PENGETAHUAN (TELAAH ATAS PEMIKIRAN SYED NAQUIB AL ATTAS DAN ISMAIL RAJI AL-FARUQI)

Ambar Hermawan 




\title{
KONSEP KEPEMIMPINAN DALAM PERSPEKTIF TEOLOGI SYIAH
}

\begin{abstract}
Kamaluddin Nurdin Marjuni
Jurusan Akidah and Studi Agama, Fakultas Kepemimpinan dan Management, Universiti Sains Islam Malaysia

kamaluddin@usim.edu.my
\end{abstract}

\begin{abstract}
Imamah (Leadership of the State) is the main factor causing disputes among Muslims until today, thus splitti ng Islam into various streams, classes and schools. The conflict between Islamic groups aft er the Prophet based on a question: who should and deserve to be the leader of the state. In the Shiite concept known as "Imamah" which mean that Shiite Imamah is not a matter of personal interest given to the general choice, but it is one of the principles and foundati ons of Islamic religious principles (Arkan ad-Din). This paper will explain the implementati on of imamah concept and the conflicts that occur in the issue of political differenti on between Shiite groups. Various problems are analyzed through Shiite primary books. This study shows that Shiite throughout the history of Islamic politics always be a dissident side.
\end{abstract}

Keyword: Leadership, Conflict of Politic, Shiite, Ahli Sunnah. 
TRANSFORMASI: Jurnal Kepemimpinan Dan Pendidikan Islam

Volume: 3 Nomor 2 Juni 2020

Konsep Kepemimpinan Dalam Perspektif Teologi Syiah...., H. 28-41

\section{PENDAHULUAN}

Kamaluddin Nurdin Marjuni

Dalam perspektif kepemimpinan Islam, ada empat komponen yang perlu terwujud dalam membina masyarakat, yaitu: Wilayah teritorial yang kondusif (al-bi'ah, al-quro), ummat (al-ummah), syari'at atau aturan (asysyariah), kepemimpinan/pemimpin (al-imamah, amirul ummah).

Dalam sejarah Islam, masalah kepemimpinan politik (imamah) merupakan persoalan yang krusial. Karena ini adalah persoalan pertama yang menimbulkan perselisihan di antara kaum muslimin. Dan perselisihan ini telah mengakibatkan terpecahnya kaum muslimin kepada beberapa jamaah, kelompok, dan aliran, terutamanya kelompok Syiah dan Sunni.

Semenjak dari masa kekhilafahan khulafa urrasyidin sehingga saat ini terjadi perselisihan di antara berbagai aliran Islam mengenai siapakah di antara kaum muslimin yang paling berhak dalam memegang tampuk imamah atau kekhilafahan.

Para ahli sejarah mengenai kajian aliran-aliran dan perbandingan agama telah mengisyaratkan hal ini, sebagaimana yang dikatakan oleh Imam al-Asy'ari: "perselisihan pertama yang timbul di antara kaum muslimin setelah kematian Nabi saw adalah perselisihan mengenai imamah". Dan asy-Syah Rastani memberikan penegasan bahwa ini adalah persoalan utama yang paling besar yang terkonsentrasi kepada per- tikaian dalam bidang politik praktis an- tara kaum muslimin, dia berkata: "dan perselisihan yang paling besar di antara umat adalah perselisihan mengenai imamah, karena di dalam Islam tidak pernah ada pedang yang teracung dalam perselisihan mengenai akidah agama sebagaimana yang terjadi dalam persoalan imamah pada semua masa" 2 .

Hal ini juga ditegaskan oleh salah seorang ahli sejarah Syiah Zaidiyah bernama Nisywan al-Humayri: "sesungguhnya perselisihan pertama yang terjadi di antara umat setelah kematian Nabi saw. dan keluarganya adalah perselisihan dalam permasalahan imamah pada peristiwa saqifah Bani Sa'idah"”.

Dari teks-teks yang dipaparkan oleh para sejarawan aliran-aliran Islam di atas ini dapat dilihat dengan jelas bahwa perselisihan utama di antara umat Islam bukanlah perselisihan pemikiran, akan tetapi hanya semata-

\footnotetext{
1 Al-Asy'ari, Maqalatu al-Islamiyyin, Hal 2.

2 Asy-Syahrastani, al-Milal wan-Nihal, 1/24.

${ }^{3}$ Nisywan al-Humyari, Syarh Risalah al-Hur al-'Ain, hal 212.
} 
mata perselisihan politik. Karena perselisihan yang timbul di antara umat Islam setelah kematian Rasulullah saw hanya terbatas kepada tampuk kekhilafahan dan kepemimpinan negara. Prof. DR. Muhammad al-Jalayand memberikan komentar mengenai hal ini: "sesungguhnya perselisihan mengenai persoalan imamah pada masa awal sejarah Islam ini bukanlah perselisihan pemikiran ataupun aliran, akan tetapi perselisihan fanatisme yang ditimbulkan oleh rasa fanatik keturunan dan aliran darah"4. Dan barangkali perselisihan inilah yang dikatakan sebagai perselisihan yang berat bagi umat Islam oleh Imam Ahmad bin al-Hasan ar-Rashshash, dalam perkataannya: "dan tidak diragukan lagi bahwa persoalan imamah termasuk perkara yang berat dan meletihkan",

\section{PEMBAHASAN}

\section{A. Kemunculan Syiah}

Syiah menurut etimologi bahasa Arab bermakna pembela dan pengikut seseorang. Selain itu juga bermakna setiap kaum yang berkumpul diatas suatu perkara. Adapun menurut terminologi syariat, Syiah bermakna mereka yang menyatakan bahwa Ali bin Abu Talib lebih utama dari seluruh sahabat dan lebih berhak untuk menjadi khalifah kaum muslimin sepeninggal Rasulullah saw. ${ }^{6}$

Dalam menelusuri kemunculan pengikut Imam Ali yang dikenal dengan penamaan sebagai kaum Syiah, perlu dilihat dari dua hal, iaitu aspek politik dan aspek akidah.

\section{Pertama: Aspek Politik dalam Kemunculan Syiah}

Kemunculan Syiah dari segi politik dimulai selepas wafatnya Nabi Muhammad saw., dan puncaknya adalah setelah pembunuhan Utsman bin 'Affan. Pada masa kekhalifahan Abu Bakar, Umar, masa-masa awal kekhalifahan Utsman yaitu pada masa tahun-tahun awal jabatannya, umat Islam bersatu, tidak ada perselisihan yang tajam. Kemudian pada akhir

${ }^{4}$ Al-Jalayand, Muhammad as-Sayyid, 1981 M, Qadhiyyatu al-Khair wasy-Syarr Fi al-Fikri al-Islami, hal 338, Kairo, Mathba'ah al-Halabi.

${ }^{5}$ Ahmad bin al-Hasan ar-Rashshash, al-Khilafah an-Nafi'ah, hal 224.

${ }^{6}$ Al-Zabidi, Taajul 'Arus, 5/405. Al-Shekh al-Mufid, Awaail al-Maqaalat, 33. Al-Shahrastani, al-Milal wa an-Nihal, 166. 
kekhalifahan Utsman terjadilah berbagai peristiwa yang mengakibatkan timbulnya perpecahan, muncullah kelompok pembuat fitnah dan kezhaliman, mereka membunuh Utsman, sehingga setelah itu umat Islam pun berpecahbelah.

Peristiwa pembunuhan Utsman menimbulkan munculnya perseteruan antara Mua'wiyah dan Ali, di mana pihak Mu'awiyah menuduh pihak Ali sebagai otak pembunuhan Utsman. Ali diangkat menjadi khalifah keempat oleh masyarakat Islam di Madinah. Pertikaian keduanya juga berlanjut dalam memperebutkan posisi kepemimpinan umat Islam setelah Mu'awiyah menolak diturunkan dari jabatannya sebagai gubernur Syiria. Konflik Ali-Muawiyah adalah titik permulaan dari konflik poli- tik besar yang membagi-bagikan umat ke dalam kelompok-kelompok aliran pemikiran.

Krisis politik sejak pengangkatan Ali bin Abi Thalib menjadi khalifah dan disusul kemudian dengan penolakan Muawiyah bin Abu Sufyan terhadap eksistensi kekhalifahan Imam Ali, dengan sendirinya telah membangkitkan ketegangan politik dari kedua belah pihak yang bertikai dan bersengketa sehingga berujung kepada terjadinya perang Siffin. Perang Siffin inilah merupakan puncak krisis politik umat Islam. Dalam sejarah dikatakan sebagai fitnah besar "al-fitnah al-kubra". Dari fitnah ini juga dikemudian hari terus menerus berkembang dan membesar dalam melukiskan proses dan perjalanan panjang sejarah politik umat Islam dari generasi ke generasi antara Sunni dan Syiah.

Dalam sejarah, sikap Ali yang menerima tawaran arbitrase (perundingan) dari Mu'awiyah dalam perang Siffin tidak disetujui oleh sebagian pengikutnya yang pada akhirnya menarik dukungannya dan berbalik memusuhi Ali. Kelompok ini kemudian disebut dengan Khawarij (orangorang yang keluar). Dengan semboyan La Hukma Illa lillah (tidak ada hukum se- lain hukum Allah), mereka mengang-gap keputusan tidak bisa diperoleh melalui arbitrase melainkan dari Allah. Mereka melabelkan orangorang yang terlibat arbitrase sebagai kafir karena telah melakukan "dosa besar" sehingga layak dibunuh?

Doktrin imamah ini dalam perkembangannya dijadikan oleh Syiah sebagai keyakinan atau kepercayaan yang agung, sehingga dapat memberi kesan dan pengaruh besar dalam sistem pemerintahan dan

${ }^{7}$ Kamaluddin Nurdin Marjuni, Nash'at al-Firaq wa Tafarruquha, 121, LebanonBeirut, Darul Kutub Ilmiah, 2011. 
kepemimpinan, kajian-kajian akidah dan teologi Islam, fiqih dan usul fiqih, mu'amalah, tafsir dan hadis. Sehingga hampir dalam semua ayatayat al-Qur'an dan Hadis Rasulullah saw. yang berkaitan dengan kepemimpinan, perwalian, penghakiman dan sebagainya, mereka masukkan nilai-nilai imamah ke dalamnya dan ditafsirkan sebagai konsep Imamah.

Hal ini menandakan bahwa persoalan teologis dalam Islam berawal dari masalah politik, sehingga memberikan pengaruh dan kesan besar terhadap perpecahan umat Islam, bahkan dapat mempengaruhi tatanan kehidupan sosial masyarakat. Dan terkadang masyarakat itu sendiri ikut langsung terlibat di dalam ranah politik, sehingga berbagai kalangan dan tingkatan sosial di masyarakat bersaing untuk menjadikan pilihan politiknya berkuasa. Dengan demikian, permasalahan awal antara Sunni dan Syiah sebenarnya bersumber pada sejarah masa lalu yang sangat bersifat politis, bukan dari segi teologi Islam.

\section{Kedua: Aspek Akidah dalam Kemunculan Syiah}

Adapun kemunculan Syiah secara akidah yang di kemudian hari dalam perkembangannya bernuansa ekstrim dan sesat, ditandai dengan penglibatan seseorang yang bernama Abdullah bin Saba' Ia adalah seorang Yahudi berasal dari San'a Yaman yang datang ke Madinah kemudian berpura-pura setia kepada Islam pada masa akhir khilafah Utsman bin Affan. Padahal dialah yang sesungguhnya mempelopori kudeta berdarah dan melakukan pembunuhan terhadap khalifah Utsman bin Affan. Dialah juga pencetus aliran akidah Syiah yang kemudian berlebihan dalam mengkultuskan (memuliakan) Ali bin Abi Thalib.

Abdullah bin Saba' mengenalkan ajarannya dari secara sembunyi hingga terang-terangan. Ia kemudian mengumpulkan orang ramai, mengumumkan bahwa kepemimpinan (imamah) sesudah Nabi Muhammad seharusnya jatuh ke tangan Ali bin Abi Thalib berdasarkan petunjuk Nabi saw.

Di antara isu-isu sesat dan menyesatkan yang disebarkan oleh Abdullah bin Saba' untuk memecah belah Umat Islam pada saat itu antara lain:

1. Ali telah menerima wasiat sebagai pengganti Rasulullah saw.

2. Imam harus dipangku oleh orang yang paling baik (Best of Man).

3. Abu Bakar, Umar dan Utsman adalah orang-orang zhalim, karena telah merampas hak khilafah Ali setelah wafatnya Rasulullah saw. Dan 
umat Islam saat itu yang membai'at ketiga khilafah tersebut dinyatakan kafir.

4. Rasulullah saw. akan kembali lagi ke dunia sebelum hari kiamat, sebagaimana kepercayaan akan kem- balinya Nabi Isa as.

5. Ali adalah pencipta semua mahluk dan pemberi rezeki.

6. Ali tidak mati, melainkan tetap hidup di angkasa.

7. Petir adalah suaranya ketika marah dan kilat adalah cemetinya. Bahwa ruh Al-Quds bereinkarnasi ke dalam diri para imam Syiah.Dan lain-lain ${ }^{8}$.

Dari sejumlah kesesatan ini, Imam an-Naubakhti, seorang ulama Syiah yang terkemuka di dalam bukunya "Firaq as-Syiah" mengatakan bahwa Imam Ali pernah hendak membunuh Abdullah bin Saba' karena fitnah dan kebohongan yang disebarkannya, yakni menganggap Ali sebagai tuhan dan mengaku dirinya sebagai nabi. Akan tetapi rencana ini tidak berhasil karena tidak ada yang setuju dengan tindakan ini. Lalu sebagai gantinya Abdullah bin Saba' dibuang ke Mada'in, ibu kota Iran pada masa itu? .

Dalam masa ini banyak pengikut Syiah yang menganggap Ali sebagai tu- han. Ketika mengetahui kemunculan sekte ini Ali membakar mereka dan membuat parit-parit di depan pintu masjid Bani Kandah untuk membakar mereka. Imam Bukhari meriwayatkan dalam kitab shahihnya, dari Ibnu Abbas ia mengatakan, "Suatu ketika Ali memerangi dan membakar orang-orang zindiq (Syiah yang menuhankan Ali). Andaikan aku yang melakukannya aku tidak akan membakar mereka karena Nabi pernah melarang melakukan pen- yiksaan sebagaimana siksaan Allah (di- bakar), akan tetapi aku pasti akan me- menggal batang leher mereka, karena Nabi bersabda:

"Barangsiapa yang mengganti agamanya (murtad) maka bunublah ia". (Bukhari, no: 2794)

\section{B. Aliran-Aliran Syiah}

Syiah berpecah kepada beberapa aliran-aliran kecil yang kesemuanya digolongkan dalam aliran yang ekstrim (Ghulat), diantaranya adalah sebagai berikut: Syiah Sabaiyyah, Syiah Kaisaniyyah, Syiah Mukhtariyyah, Syiah Syiah Hashimiyyah, Syiah Bayaniyyah, Syiah Rizamiyah.

${ }^{8}$ Lihat rujukan berikut: Al- Naubakhti, Firaq Al Syi'ah, 44. Al Baghdadi, Al Farq Baina Al Firaq, 234. Kamaluddin Nurdin Marjuni, al Firaq al-Syi'iyyah wa Ushuluha al Siyaasiyyah. 7-9.

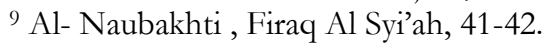


Kemudian Syiah berpecah kepada aliran-aliran yang besar, dan dapat dibatasi kepada tiga aliran saja sebagaimana yang dinyatakan oleh Imam Ahmad bin Yahya al-Murtadha (w. $840 \mathrm{H}$ ) dalam kitabnya yang terkenal "al-Bahru alZahhar". Beliau mengatakan bahwa ada tiga golongan besar Syiah, yaitu: Zaidiyah, Imamiyah dan Isma'iliyah (di kenal dengan Syiah Bathiniyah) ${ }^{10}$.

Ketiga aliran tersebut masih eksis sampai saat ini, yaitu Syiah Zaidiyah, Syiah Imamiyah dan Syiah Isma'iliyah. Dan Syiah Zaidiyah didirikan oleh Imam Zaid. Sedangkan Syiah Imamiyah yang memiliki karakteristik yang berupa pengakuan terhadap kepemimpinan dua belas imam yang didirikan oleh Musa bin Ja'far (al-Kadzim) sebagai imam yang ketujuh dari urutan kepemimpinan. Di samping itu golongan ini juga diberikan julukan al-Ja'fariyah, karena berbagai pandangan fiqh mereka bersandarkan kepada pendapat Imam Ja'far ash-Shadiq. Adapun Syiah Isma'iliyah didirikan oleh Isma'il bin Ja'far, golongan ini sebenarnya adalah bentuk perpanjangan golongan ekstrimis Syiah (Ghulat) dan dikenal dengan nama Syiah Bathiniyah. Penamaan Syiah Isma'iliyah terus melekat sampai berdirinya dinasti Fathimiah pada tahun 296 H. Maka pada masa tersebut nama isma'iliyah diganti dengan nama baru, yaitu "al-Fathimiah". Kemudian, nama isma'iliyah kembali dipergunakan setelah dinasti Fathimiah mengalami kehancuran pada tahun $566 \mathrm{H}$. Dan pada masa peperangan salib, kelompok Syiah Isma'iliyah ini terkenal dengan julukan "al-Hasysyasyin" atau "Assassins".

Kedua-Belas-Imam yang diakui oleh aliran Syiah Imamiyah Itsna As-yariyah adalah sebagai berikut:

1. Ali ibn Abi Thalib "al-Murtadha" (w. 40 H/661 M)

2. Al-Hasan bin 'Ali "az-Zaky" (w. 49H/669 M)

3. Al-Husein bin 'Ali "Sayyid asy-Syu- hada" (w. 61 H/680 M)

4. Ali bin Al-Husein, Zain Al-Abidin "Zainal 'Abidin" (w. 95 H/714 M)

5. Abu Ja'far Muhammad Ali "Al-Baqir” (w. 115 H/733 M)

6. Abu Abdillah Ja'far bin Muham- mad "Ash-Shadiq" (w. 148 $\mathrm{H} / 765 \mathrm{M})$

7. Abu Ibrahim Musa bin Ja'far "Al-Kazhim" (w. 183 H/799 M)

8. Abu Hasan Ali bin Musa "Ar-Ridha" (w. 203 H/818 M)

9. Abu Ja'far Muhammad bin Ali "al- Jawad" Al-Taqi (w. 220 H/835 M)

10. Abu Hasan Ali bin Muhammad "al- Hadi" (w. 254H/868 M)

11. Abu Muhammad Al-Hasan bin Ali "Al-Askari” (w. 260 H/874 M)

${ }^{10}$ Ahmad Bin Yahya al-Murtadha, al-Bahr al-Zahhar, 1/32, Darul Kutub Ilmiah, Beirut-Lebanon, 2001. 
12. Abu al-Qasim Muhammad bin Hasan "Al-Mahdi", Al-Qa'im AlHujjah (memasuki kegaiban besar pada 329 H/940 M).

Dengan demikian dari ketiga aliran Syiah di atas yang paling terkenal, terbesar dan memiliki jumlah pengikut yang banyak ialah aliran Syiah Itsna Asyariyah atau Syiah Ja'fariyyah yang merangkumi kurang lebih 90\% penduduk di Iran dan sebagian besar penduduk Irak dan Lebanon.

Kemunculan Syiah Zaidiyah dimulai ketika Imam Zaid melancarkan revolusi melawan pemerintahan Bani Umayyah, yang didukung oleh lima belas ribu pasukan berasal dari penduduk Kufah di Iraq, di mana hal serupa dilakukan sebelumnya oleh kakek Imam Zaid yaitu Imam Husein bin Ali bin Abi Talib, dan mengalami kegagalan fatal dalam pertempuran di kota Karbala, dengan menewaskan 61 tentara Imam Husein bin Ali. Namun selanjutnya Imam Zaid tidak menerima kegagalan tersebut, justru ia bersikeras untuk meneruskan revolusi kakeknya dan terus menerus memerangi Bani Umayyah sampai titik darah penghabisan. Maka ia dan bala tentaranya meninggalkan kota Kufah menuju tempat kekuasaan gubernur (Yusuf bin Umar ats-Tsaqafi) yang merupakan agen kepala negara ketika itu (Hisyam bin Abdul Malik bin Marwan) yang berkuasa dari tahun 105 sampai tahun 125 Hijriyah.

Tatkala kedua pasukan terse- but bertemu dan saling berhadapha- dapan, dan sebelum kedua pasukan tersebut memulai peperangan, maka pasukan Imam Zaid yang berasal dari penduduk Kufah berkata kepada Imam Zaid: "Kami akan mendukung perjuan- ganmu, namun sebelumnya kami ingin tahu terlebih dahulu sikapmu terh- adap Abu Bakar Siddiq dan Umar bin Khattab di mana kedua-duanya telah menzalimi kakekmu Imam Ali bin Abi Thalib". Imam Zaid menjawab: "bagi saya mereka berdua adalah orang yang baik, dan saya tak pernah menden- gar ucapan dari ayahku Imam Zainal Abidin tentang perihal keduanya ke- cuali kebaikan. Dan kalaulah saat ini saya berani melawan dan menantang perang Bani Umayyah, itu disebabkan karena mereka telah membunuh kakek saya (imam Husein bin Ali). Di samp- ing itu, mereka telah memberangus- kan kota Madinah di tengah teriknya matahari pada siang hari. Ketika itu terjadilah peperangan sengit di pintu Tiba kota Madinah. Dan tentara Yazid bin Mu'awiyah (w 63H) ketika itu telah menginjak-injak kehormatan kami, dan membunuh beberapa orang sahabat. Dan mereka menghujani mesjid dengan lemparan batu dan api".

Setelah mendengar sikap dan jawaban Imam Zaid, para tentara Kufah meninggalkan Imam Zaid. Dan Imam Zaid berkata kepada mereka: 
"kalian telah menolak saya, kalian telah menolak saya"11. Semenjak hari itu tentara tersebut dikenal dengan nama (Ra-fidhah). Mereka inilah yang di kemudi- an hari dikenal dengan nama golongan Syiah Imamiyah al-Itsna 'Asyariyah. Peristiwa inilah yang menjadi akar sejarah penggunaan istilah (Rafidhah) bagi golongan Syiah Imamiyah, yang di tandai dengan penolakan dukungan perang mereka bersama Imam Zaid untuk menghadapi gubernur Iraq ketika itu (Yusuf bin Umar at-Tsaqafi). Sejarah ini dicatat oleh salah satu sejarawan dan ulama Zaidiyah yang bernama Nisywan al-Humairi (w 573H). Dan dia menegaskan bahwa penamaan Rafidhah bagi golongan Syiah disebabkan oleh penolakan mereka untuk membantu Imam Zaid berpeperang melawan Bani Umayyah. Yaitu, ketika mereka menanyakan sikap Imam Zaid terhadap Abu Bakar dan Umar, dan ternyata Imam Zaid memberikan tanggapan yang positif terhadap kedua mantan khalifah tersebut).

Syiah Zaidiyah merupakan golongan Syiah yang sangat moderat dan terbuka bagi aliran-aliran lain dalam Islam, di mana Zaidiyah menganggap perlunya kontinuitas ijtihad. Dalam artian, pintu ijtihad harus dibuka selebar-lebarnya. Sebab menurut Imam Syaukani: "Seseorang yang hanya mengandalkan taqlid (mengikut pandangan tertentu) seumur hidupnya tidak akan pernah bertanya kepada sumber asli yaitu "al-Qur'an dan Hadits", dan ia hanya bertanya kepada pemimpin mazhabnya. Dan orang yang senantiasa bertanya kepada sumber asli Islam tidak dikatagorikan sebagai Muqa- llid (pengikut)"12. Berdasarkan atas kedudukan dan pentingnya ijitihad, maka bagi Syiah Zaidiyah bertaqlid hukumnya haram bagi siapa saja yang mampu mencapai tingkatan mujtahid, sebab ia diwajibkan untuk melakukan ijtihad demi mencari nilai kebenaran.

Dalam penilaian syekh Abu Zuhrah, Syiah Zaidiyah pada hakikatnya memberikan pilihan bebas kepa- da penganutnya untuk memakai pandangan mazhab-mazhab Islam lainnya, dengan cara memilih pandangan yang sesuai dengan bukti atau dalil. Dan dalil tersebut tidak bertentangan den- gan pegangan umum yang disepakati oleh Syiah Zaidiyah. Dan sikap mereka sebenarnya merealisasikan ucapan para imamimam mazhab yang menga- takan: "Tidak sah bagi seseorang memakai

11 Al-Baghdadi, al-Farq Baina al-Firaq, 25, Darul Afaq al-Jadidah, Beirut-Lebanon, 1997. Al-Asy'ari, Maqalat al-Islamiyyin, 65, Dar Ihya at-Turats al-'Arabi, Beirut-Lebanon, tanpa tahun.

12 asy-Syaukani, al-Badru at-Taali', 2/135. 
pendapat kami, kecuali ia tahu sendiri sumber aslinya (al-Qur"an dan asSunnah“'13. Dengan konsep keterbukaan ijtihad inilah yang membuat Syiah Zaidiyah kaya akan pandangan dan pemikiran agama. Sehingga ada sebagian dari ulama mereka yang ditemukan menganut corak berpikir golongan lain.

Disamping itu, perlu dicatat bahwa Syiah secara umum tercatat dalam sejarah politik Islam senantiasa memasang sikap oposisi terhadap pemerintah atau kerajaan. Dan cara oposisinya bervariasai antara satu dengan yang lainnya. Kalau Syiah Zaidiyah, sikap oposisi mereka secara terangerangan, atau dalam istilah mereka dikenal dengan "al-Khuruj", atau frontal, dan bila perlu melakukan revolusi secara besar-besaran. Namun berbeda dengan golongan Syiah lainnya (Imamiyah dan Isma'ilyah). Mereka memilih oposisi dengan cara rahasia, alias gerakan bawah tanah (tersembunyi), atau dalam istilah mereka dike- nal sebagai "Taqiyah", atau diam-diam, tak mendeklarasikan diri dan identitas asli.

\section{Dasar-Dasar Konsep Kepemi- mpinan Aliran-Aliran Syiah}

Syi'ah dan politik dua kata yang tidak mungkin dipisahkan. Dibanding dengan Sunni dalam gerakan dakwah, Syi'ah lebih menonjolkan nilai politik dibanding nilai teologi. Dilihat dari aspek sejarahnya pun, Syiah memang lahir karena faktor politik, yakni menyangkut masalah siapa yang berhak menggantikan kepemimpinan Nabi Muhammad saw. sepeninggal beliau. Oleh karena itu dalam hadits riwayat syiah di bawah ini sangat aneh kalau dibandingkan dengan rukun iman golongan Ahli Sunnah. Riwayat berikut berbunyi:

"Dari 'Ujlan Abu Shalih, ia bekata: "Saya meminta penjelasan dari Abu Abdillah tentang batasan-batasan iman, ia menjawab bahwa iman adalah: "Bersaksi bahwa ti ada Tuhan yang berhak disembah selain Allah, dan bahwa Nabi Muhammad adalah utusan Allah, dan berikrar (mengakui) segala yang datangnya dari Allah, mendirikan solat, menunaikan zakat, puasa ramadhan, melaksanakan haji, percaya kepada Walayah (Imamah), dan memerangi musuhmusuh, dan berhimpun bersama orang-orang yang benar (jujur)" ${ }^{\text {"14 }}$.

Bila diperhati kan riwayat di atas, nampaknya syi'ah Imamiyah menggabungkan antara rukun iman dan rukun Islam (mengucap dua kalimat syahadat), dan tidak disebutkan sama sekali didalamnya tentang keimanan kepada

\footnotetext{
13 Abu Zuhra, al-Imam Zaid, 484-485, Darul Fikri Arabi, Kairo, tanpa tahun.

14 Al-Kulaini, Ushul al-Kaafi , 2/42.
} 

para malaikat, kitab-kitab, para rasul, hari kiamat dan qadha dan qadar. Ditempat lain seorang ulama terkenal syiah Imamiyah bernama Sheikh Zayn al-Din Ali ibn Muhammad al-Jab'i al-Amili menegaskan bahwa ti ang keimanan terletak pada lima hal: (1) Ma'rifat Allah. (2) Mengakui keadilan Allah swt. (3) Mengakui kenabian Nabi Muhammad saw. (4) Mengakui imam 12. (5) Percaya kepada kebangkitan jasmani ${ }^{15}$.

Dari sini ti mbul pertanyaan apakah mereka percaya kepada para Malaikat, kitab-kitab dan qadha dan qadar? Pada hakikatnya, mereka percaya kepada para malaikat, kitab-kitab dan qadha dan qadar, namun tidak dinyatakan secara tekstual dalam rukun iman mereka seperti halnya rukun iman sunni yang secara tekstual tertuang dengan jelas dalam hadis dialog antara malaikat dan Umar bin Khatab, oleh karena itu setelah meniliti persoalan ini di kitab-kitab syiah, maka nampak bahawa dalil yang diajukan oleh syiah dalam perbincangan keimanan kepada malaikat, kitab dan qadha dan qadar adalah dalil-dalil Qur'an, seperti firman Allah swt:

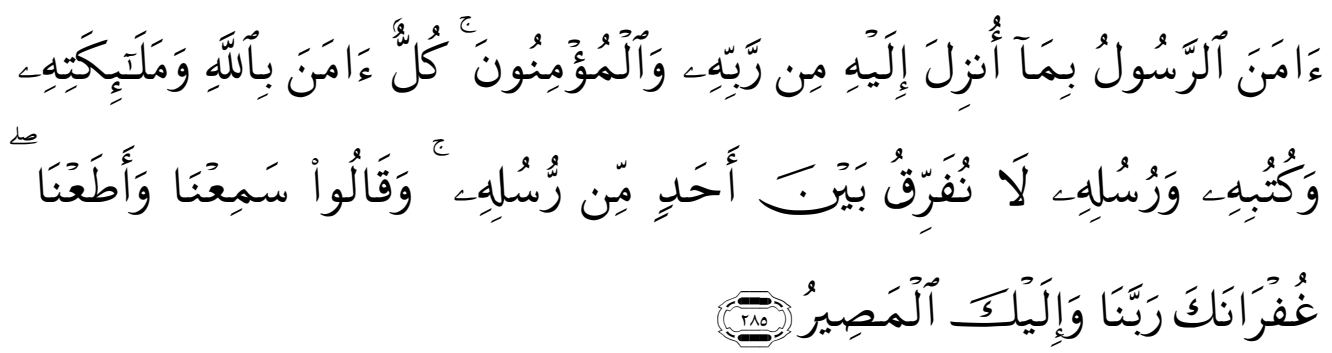

Terjemahnya:

Rasul telah beriman kepada Al Quran yang diturunkan kepadanya dari Tuhannya, demikian pula orang-orang yang beriman. semuanya beriman kepada Allah, malaikat-malaikat-Nya, kitab-kitab-Nya dan rasul-rasulNya. (mereka mengatakan): "Kami tidak membeda-bedakan antara seseorangpun (dengan yang lain) dari rasul-rasul-Nya", dan mereka mengatakan: "Kami dengar dan Kami taat." (mereka berdoa): "Ampunilah Kami Ya Tuhan Kami dan kepada Engkaulah tempat kembali." (Q.S. al-baqarah: 285)

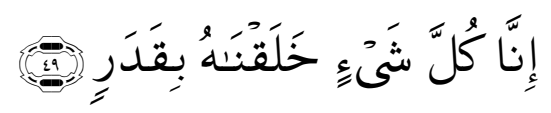

Terjemahnya:

15 Al-Sayyid Abdullah Syibr, Haqqul Yaqin fi Ma'rifat Ushul al-Din, 564-570. Mu'assah al-'Alamy, Beirut, 1997. 
Sesungguhnya Kami menciptakan segala sesuatu menurut ukuran. (AlQamar: 49)

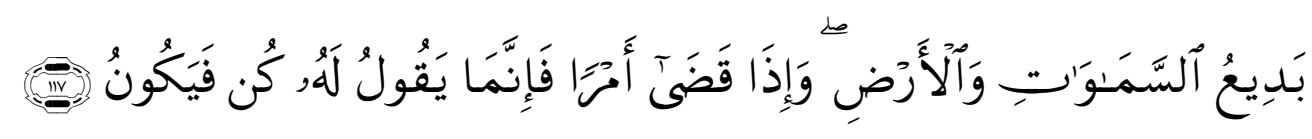

Terjemahnya:

Allah Pencipta langit dan bumi, dan bila Dia berkehendak (untuk menciptakan) sesuatu, Maka (cukuplah) Dia hanya mengatakan kepadanya: "Jadilah!" lalu jadilah ia. (Al Baqarah: 117)

Seorang ulama syiah bernama Imam Ja'far Subhani menegaskan bahawa keimanan kepada qadha dan qadar adalah wajib dipercayai seyakin-yakinnya dan ti dak boleh diingkari sama sekali' ${ }^{16}$. Dengan demikian, para ulama syiah imamiyah membincangkan rukun iman mereka dalam berbagai kitab. Di antaranya ada yang memasukkan perkara iman kepada qadha dan qadar dalam bab al-Adl (Iman kepada keadilan Allah). Begitu juga iman kepada para malaikat terkadang dimasukkan dalam perbincangan al-Nubuwwah (iman kepada kenabian) ${ }^{17}$.

Apapun halnya, hadits Syiah tentang rukun Iman di atas yang diriwayatkan oleh Ujlan Abu Shalih dijadikan oleh golongan Syiah sebagai pedoman dalil wajibnya penganut Syiah menyatakan diri taat setia kepada imam di setiap zaman, kemudian sistim pemerintahan yang dipakai adalah sistim imamah, yaitu suatu doktrin kepemimpinan politik yang menyebutkan bahwa pemerintahan Islam sepeninggal Nabi saw. adalah hak mutlak ahlul bait (keluarga Nabi saw.) yakni Ali dan sebelas imam lainnya.

\section{Kepemimpinan Melalui Nash}

Pengangkatan atau penunjukan imam dalam teologi Syiah merupakan hak preogratif Allah swt., yang disampaikan melalui wahyu dan lisan Rasulullah saw. Manusia ti dak memiliki peran dalam hal ini sehingga tidak mempunyai kelayakan untuk ikut memilih dan mengangkat seorang imam, disebabkan penentuan seorang imam adalah berdasarkan kelayakan kepribadian khas (zati yah), yakni keabsahan, yang mana pada diri seseorang telah tertanam sifat-sifat dan kriteria imam seperti sifat ishmah (terpelihara dari kesalahan dan dosa), disamping itu memiliki ilmu secara sempurna dan telah menjadi jati

\footnotetext{
16 Ja'far Subhani, al-Aqidah al-Islamiah fi Madrasah Ahlil Bait, 102, 420.

17 Al-Hurr al-Amili, al-Fusul al-Muhimmah fi Usul al-Aimmah, 80-81.
} 
dirinya. Atas dasar ini, kepemimpinan (imamah) dalam pandangan syiah tidak hanya merupakan suatu sistem pemerintahan, tetapi juga rancangan Allah swt. yang muthlak (absolute) tanpa dibatasi apapun, dan menjadi dasar syariat yang kepercayaan kepadanya dianggap sebagai pengukuh dan syarat sahnya keimanan.

Semua aliran Syiah Zaidiyah, Imamiyah, Isma'iliyah- walaupun saling berbeda kelompok, aliran, dan pendapatmereka sepakat bahwa keti ga imam: Ali bin Abi Thalib, dan kedua putranya Hasan dan Husein, telah ditentukan dan diangkat menjadi pemimpin melalui "Nash/Teks" dari Allah dan Rasul-Nya. Adapun dalil yang mereka pergunakan untuk menguatkan pendapat mereka terdiri dari Qur`an dan Sunnah.

Yang paling utama adalah dalil dari alQur`an, yang berupa fi rman Allah swt yang berbunyi:

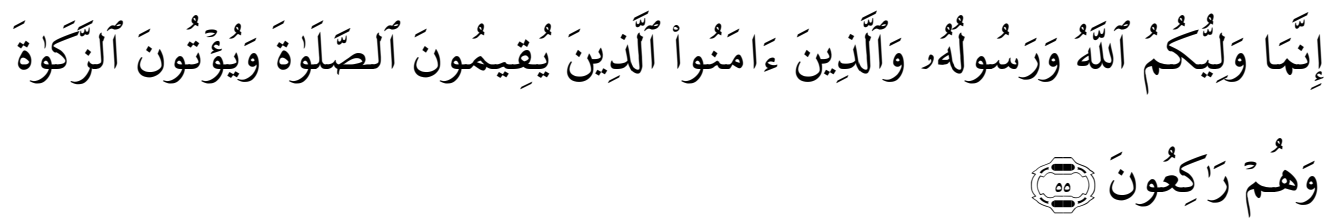

Terjemahnya:

Sesungguhnya penolong kamu hanyalah Allah, Rasul-Nya, dan orangorang yang beriman, yang mendirikan shalat dan menunaikan zakat, seraya mereka tunduk (kepada Allah). (Al-Maidah/55)

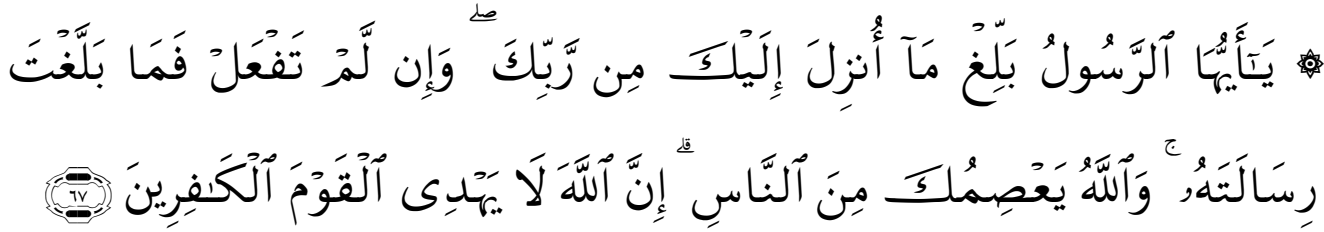

Terjemahnya:

Hai rasul, sampaikanlah apa yang diturunkan kepadamu dari Tuhanmu. dan jika tidak kamu kerjakan (apa yang diperintahkan itu, berarti) kamu tidak menyampaikan amanat-Nya. Allah memelihara kamu dari (gangguan) manusia. Sesungguhnya Allah tidak memberi petunjuk kepada orang-orang yang kafir. (Al-Maidah/67).

Sedangkan dalil dari Sunnah adalah sabda Rasulullah saw pada peristi wa al-Ghadir:

Artinya:

"Wahai manusia, bukankah aku lebih utama pada kalian dibandingkan diri kalian? Mereka menjawab: betul, beliau kembali berkata: barang siapa 
yang menjadikan aku sebagai panutannya maka Ali juga menjadi panutannya. Ya Allah jadikanlah wali orang yang menjadikan Ali sebagai walinya, musuhilah orang yang memusuhi Ali, tolonglah orang yang menolong Ali, dan kecewakanlah orang yang mengecewakan Ali”. (Ahmad, no: 641)

Sabda Rasulullah saw kepada Ali ra Artinya:

"Kedudukan kamu bagiku sama dengan kedudukan Harun bagi Musa, kecuali ti dak ada nabi sesudahku”. (Muslim, no: 4418)

Sabda Rasulullah saw:

Artinya:

"Hasan dan Husein adalah tuan para pemuda penghuni syurga". (Ahmad, no: 11192)

\section{Sabda Rasulullah saw:}

Artinya:

"Hasan dan Husein adalah dua orang imam, baik keduanya dalam dalam keadaan berdiri ataupun dalam keadaan duduk". (Ibnu Babwaih, Ilal alSyaraa'i) Riwayat ini ti ada dalam kitab-kitab hadis Ahli Sunnah. Semua dalil ini menurut pandangan Syiah menunjukkan kepemimpinan Ali bin Abi Thalib, Hasan dan Husein ${ }^{18}$.

Hipotesa dari teologi Syiah mengenai keberadaan Nash atau wasiat ini adalah, mereka memiliki pandangan bahwa kaum muslimin yang terdiri dari kaum muhajirin dan anshar telah menyembunyikan Nash ini. Oleh karena itu, mereka berhak untuk dikafirkan dan disifati sebagai munafik karena perbuatan mereka menyembunyikan Nash dan wasiat dari Nabi saw ini untuk imam Ali. Meskipun mereka bersepakat terhadap dalil mengenai keimamahan Ali, Hasan, dan Husein, akan tetapi mereka berselisih pendapat yang terbagi kepada dua kelompok mengenai apakah penentuan "nash-nash" ini bersifat terang-terangan (zahir) ataupun tersembunyi (batin/khafiy). Syiah Zaidiyah berpendapat bahwa penentuan "nash" ini bersifat tersembunyi (batin) mengenai keimamahan Ali bin Abi Thalib.

Sedangkan keimamahan Hasan dan Husein berlandaskan dalil yang jelas 55.

18 Silahkan rujuk, al-Mashadir az-Zaidiyyah, al-Qasim ar-Rassi, Tatsbit al-Imamah, hal 
(zahir). Sedangkan Syiah Imamiyah ${ }^{19}$ dan Syiah Isma'iliyah ${ }^{20}$ meyakini bahwa pengangkatan semua imam mereka ditentukan dengan "Nash Jaliy" atau ketentuannya sudah termaktub dan ditetapkan dengan jelas. Maknanya adalah sebagaimana yang dijelaskan Nisywan al-Humyari: "sesungguhnya Rasulullah saw menentukan "Nash Jaliy" mengenai kepemimpinan (imamah) Ali as dengan menyebutkan secara jelas nama, kepribadian dan nasabnya" ${ }^{21}$.

\section{E. Konflik Pemikiran Politik Aliran-Aliran Syiah}

Yang menarik, terdapat golongan Sy'iah yang merupakan bagian aliran Sy'iah yang moderat yaitu Sy'iah Zaidiyah. Sehingga aliran Syiah ini dikategorikan sebagai aliran yang paling dekat kepada kalangan Sunni. Karena aliran ini dalam banyak hal tidak sependapat dengan Sy'iah pada umumnya. Mereka tidak menyetarakan posisi imam seperti posisi Nabi yang mempunyai sifat ma'shum, dan ia sama dengan manusia yang lainnya. Oleh karena itu pada umumnya prinsip kepemimpinan politik setiap aliran-aliran Syiah saling berbeda antara satu sama lain, sebagaimana berikut:

\section{Pertama: Legitimasi Kepemimpinan Khalifah Abu Bakar, Umar dan Utsman}

Teologi Syiah Zaidiyah bertoleransi dengan kepemimpinan khulafaaurrasyidin, yang dibukti kan dengan mengakui kepemimpinan mereka terutama Abu Bakar, di mata Syiah Zaidiyah beliau tidak sesat apalagi kafir, oleh karena itu mereka mengatakan bahawa boleh mengangkat seorang pemimpin (Abu Bakar) sekalipun ada yang lebih layak darinya (Ali bin Abi Thalib) ${ }^{22}$.

Akan tetapi ide ini bukan aturan umum dalam aliran Syiah Zaidiyah, sebab kalau dimutlakkan maka akan gugur konsep revolusi (al-Khuruj). Teori tersebut diperkenalkan oleh Imam Zaid dengan tujuan membenarkan legiti masi kepemimpinan Abu Bakar, dan menggugurkan gugatan orang yang mencelanya. Oleh karena itu, setelah masa Imam Zaid, maka para pengikutnya mengubah konsep tersebut dengan mewajibkan memilih seorang pemimpin yang paling

\footnotetext{
${ }^{19}$ Lih, an-Naubakhti, Firaq asy-Syi'ah, hal 29.

${ }^{20}$ Lih, ad-Da'i Abu Ya'qub as-Sajastani, Kitab al-Iqti shar, hal 68.

${ }^{21}$ Nasywan al-Humairi, Syarh Risalah al-Hur al-'Ain, hal 157.

22 Konsep ini juga dibahas dalam kajian kepemimpinan politik Ahli Sunnah dalam bab imam Qurthubi membolehkan terjadinya seorang yang diangkat dan dipilih meskipun ada yang lebih layak dan hebat darinya. Al-Qurthubi, al-Jami' li Ahkam al-Qur'an, 1/187. Lihat rinciannya: Kamaluddin Nurdin, Masaail al-I'tiqah Inda alImam al-Qurthubi, 314. Muassasah al"Alya, Cairo, 2009. (tesis maters di Darul Ulum, Universitas Kairo, 2002)
} 
layak dari sekian calon pemimpin. Dan menurut mereka ada empat kelayakan dan kredibilitas yang mesti ada dalam diri seorang pemimpin, yaitu:

1. Memiliki keberanian untuk membela agama, dan tidak takut kepada siapapun kecuali Allah swt.

2. Bersifat Zuhud di dunia ini dan hanya mengharapkan balasan akhirat semata.

3. Faham akan kemaslahatan dan kepenti ngan rakyat dan agama.

4. Berjuang dengan pedang. Barang siapa yang memiliki ciri khas di atas maka wajib didahulukan dan diangkat menjadi seorang pemimpin umat ${ }^{23}$. Adapun Syiah Imamiyah dan Syiah Isma'iliyah dalam berbagai kitab-kitab dan penulisan klasik dan kontemporer hingga saat ini, mereka tidak mengakui kepemimpinan Abu Bakr, Umar dan Utsman, ditemui banyak ucapan-ucapan kafir, laknat, cacian, dan makian yang ditujukan kepada para sahabat Rasulullah saw.

Sebagai contoh, Al-Kulaini dalam kitabnya "Ushul al-Kafi " telah meriwayatkan dari Abdullah as, ia berkata: " aku mendengar ia berkata: "tiga jenis manusia yang tidak diajak bicara oleh Allah pada hari kiamat, mereka tidak disucikan, dan mereka mendapatkan azab yang pedih, adalah: orang yang mengklaim kepimpinan (imamah) dari Allah sedangkan itu bukanlah miliknya, orang yang menolak imam yang telah ditentukan dari Allah, dan orang yang mengklaim bahawa keduanya memiliki bagian dalam islam". (al-Kulayni: 1418).

Kedua orang tersebut bagi mereka adalah Abu Bakar ra dan Umar ra.

Di tempat yang lain, Al-Kulayni meriwayatkan dari Abdullah mengenai firman Allah Azza wa Jalla:

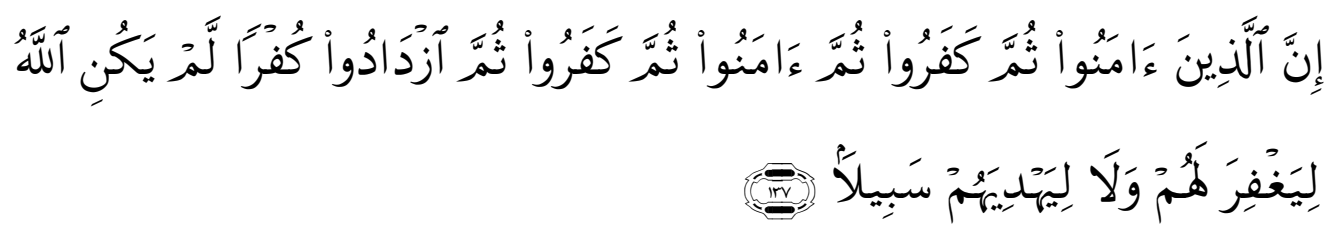

Terjemahnya:

Sesungguhnya orang-orang yang beriman kemudian kafir, kemudian beriman (pula), kamudian kafir lagi, kemudian bertambah kekafirannya, Maka sekali-kali Allah tidak akan memberi ampunan kepada mereka, dan tidak (pula) menunjuki mereka kepada jalan yang lurus. (Al-Nisaa: 137)

Dia berkata: ayat ini diturunkan untuk membicarakan si Fulan (Abu

${ }^{23}$ Kamaluddin Nurdin Marjuni, al-Firaq as-Syi'iayyah Wa Ushuluha as-Siyasiyah, hal: 3. Universiti Sains Islam Malaysia. 2009. 
Bakr), si Fulan (Umar), dan si Fulan (Usman). Pada mulanya mereka itu beriman kepada Nabi saw., lalu mereka kafir manakala ditawarkan kekuasaan kepada mereka, manakala Nabi saw. bersabda: "barang siapa yang menjadikan aku sebagai penguasanya maka Ali menjadi penguasanya". Kemudian mereka beriman dengan pembay'atan Amirul mukminin, kemudian mereka kafir manakala Rasulullah saw meninggal dunia, dan mereka tidak mengakui pembay'atan Rasulullah terhadap Ali-, kemudian kekafi ran mereka bertambah manakala mereka mengakui pembay'atan orang yang membay'at mereka, maka mereka itu sama sekali ti dak tersisa keimanan dalam diri mereka". (Al-Kulayni: 1418).

Masih banyak lagi sumber kitab Syiah Imamiyah dan Syiah Isma'iliyah yang senada dengan di atas dari segi penyesatan, pelaknatan dan pengkafiran sahabat, seperti di bawah:

Dari Abu Ja'far 'alaihis-salaam, ia berkata : “Orang-orang (iaitu para shahabat Abul-Jauzaa') menjadi murtad sepeninggal Nabi saw kecuali ti ga orang”. Aku (perawi) berkata : "Siapakah ti ga orang tersebut ?” Abu Ja'far menjawab : "Al-Miqdaad, Abu Dzarr Al-Ghiff aariy, dan Salmaan Al-Faarisiy rahimahullah wa barakaatuhu 'alaihim ...”. (Al-Majlisi: 1983).

Riwayat Syiah lain mengesahkan bahawa hanya ada 7 sahabat yang terselamat dan tidak tergolong kafir, seperti riwayat berikut:

Dari Abu 'Abdillah 'alaihis salaam, ia berkata :

“.......Demi Allah, mereka (para shahabat) telah binasa kecuali ti ga orang : Salmaan Al-Faarisi, Abu Dzarr, dan Al-Miqdaad. Dan kemudian menyusul mereka 'Ammaar, Abu Saasaan, Huzaifah, dan Abu 'Amarah sehingga jumlah mereka menjadi tujuh orang”. (Al-Majlisi: 1983).

Dari Abu Bashiir, dari salah seorang dari dua imam 'alaihimas- salaam, ia berkata: "Sesungguhnya penduduk Makkah kafir kepada Allah secara terangterangan. Dan penduduk Madinah lebih busuk/ jelek daripada penduduk Makkah 70 kali”". (Al-Majlisi: 1983).

Shekh Al-Mufi d berkata :

"Madzhab Imamiyyah telah bersepakat bahawa siapa saja yang mengingkari imamah salah seorang di antara para imam, dan mengingkari apa yang telah Allah ta'ala wajibkan padanya tentang kewajiban taat, maka ia kafi $r$ lagi sesat, dan berhak atas kekekalan di neraka" ${ }^{24}$.

Dalam kitab “'Zahru al-Ma'ani” karangan seorang ulama Syiah Isma'iliyah bernama Idris Imaduddin mengatakan: "manakala Muhammad saw merupakan

${ }^{24}$ al-Mufi d, Awail al-Maqalat, 1364. 
penyempurna bagi para nabi yang sebelumnya, maka pada masa risalahnya terkumpul musuh-musuh yang besar dan tangguh. Sebagaimana yang difi rmankan oleh Allah taala:



Terjemahnya:

dan seperti itulah, telah Kami adakan bagi tiap-tiap Nabi, musuh dari orang-orang yang berdosa. dan cukuplah Tuhanmu menjadi pemberi petunjuk dan penolong.

Di antara musuh Nabi Muhammad adalah Abu Lahab. Dan Abdul Muththalib merasa takabur manakala kemuliaan mulai nampak pada diri Muhammad, dan dia bermaksiat sebagaimana kemaksiatan al-Harts bin Murrah, sikapnya semakin keras dan takabur. Para pendukungnya pada kemaksiatan tersebut adalah Abu Jahal bin Hisyam, Ibnu Abi Qahafah (Abu Bakar), dan Ibnul Khaththab. Dia bagaikan tangan setan untuk Abu Jahal yang lemah, dan dia bagaikan tangan Utaiq. Dan Umar adalah seorang yang perkasa, maka mereka berbuat kemakaran, kekafi ran, kekerasan, keso mbongan, mereka rubah dan rusak syari'at Islam,"25

\section{Kedua: Pemimpin dari Keturunan Fatimah}

Syiah Zaidiyah mengatakan bahwa pemimpin mesti dari keturunan Fati mah, baik dari garis keturunan Hasan ataupun Husein ${ }^{26}$. Adapun Syiah Imamiyah dan Syiah Isma'iliyah hanya mengakui pemimpin yang berasal dari garis keturunan Husein saja ${ }^{27}$. Oleh karena itu pemimpin negara yang berasal dari keturunan Hasan ti dak sah bagi keduanya. Tentunya ini masalah dalaman yang aneh pada konsep pemikiran politi k Syiah, sehingga menjadi sengketa dan perseteruan utama antara mereka untuk merebut kekuasaan, dengan cara saling menyesatkan, memfasikkan bahkan mengkafi rkan satu sama lain hanya karana perbedaan garis keturunan ini.

Namun pada fakta yang terjadi, yang memoti vasi Syiah Imamiyah dan Syiah Isma'iliyah untuk membatasi kelayakan pimpinan dari garis keturunan

${ }^{25}$ Lih, ad-Da'i Idris Imaduddin, Kitab Zahrul Ma'ani, hal 155

${ }^{26}$ Abu al-Qasim Muhammad al-Hautsi, al-Mau'izhah alHasnah, hal: 104. Muhammad bin Hasan ad-Daylami, Qawa'id 'Aqaaid Aali Muhammad, hal: 49.

${ }^{27}$ Al-Qadhi an-Nu'man, Da'aim al-Islam, 1/37-38. ad-Da’i Ali Bin Walid, Damighu alBathil, 2/18. ad-Da’i Idris 'Imaduddin, Kitab Zahru al-Ma’ani, hal: 183. 
Husein saja disebabkan karena Imam Hasan mengundurkan diri dari suksesi yang terjadi antara dia dengan Muawiyah bin Abu Sufyan. Dalam suksesi tersebut, Imam Hasan menyerahkan bulat-bulat tongkat kepemimpinan kepada Muawiyah bin Abu Sufyan tanpa dilakukan pemilihan. Disebabkan oleh peristiwa inilah yang membuat Syiah Imamiyah dan Syiah Isma'iliyah tidak memberikan kesempatan kepada garis keturunan Imam Hasan untuk menjadi pemimpin. Dan dengan peristiwa ini pulalah Syiah Isma'ilyah memunculkan teori politi $\mathrm{k}$ baru yang tiada dan tidak dikenal sebelumnya oleh aliran Syiah lain, yaitu: imam tetap (al-Imam al-Mustaqir) dan Imam sementara (al-Imam al-Mustauda'). Tujuan teori ini untuk menutupi kekosongan pimpinan dari garis keturunan Imam Ali ra. yang timbul akibat terdapat kecacatan pada urutan suksesi pada serangkaian imam. Oleh karena itu, dalam asumsi Syiah Isma'iliyah Imam Hasan adalah Imam sementara sebab ia melepaskan jabatannya.

\section{Ketiga: Imam Ma'sum.}

Mengenai kema'suman imam, Syiah Imamiyah dan Syiah Isma'iliyah sepakat bahawa seluruh imam memiliki sifat ma'sum, adapun Syiah Zaidiyah dalam hal ini mereka berbeda pandangan seperti berikut:

1. Sifat ma'sum hanya dimiliki oleh Ali bin Abi Thalib saja.

2. Sifat ma'sum hanya dimiliki oleh Ahli Kisa, yaitu: Ali, Fati mah, Hasan dan Husein.

3. Sifat ma'sum untuk semua imam.

Namun dalam kajian mendalam, didapati bahwa mayoritas Syiah Zaidiyah berpendapat bahwa sifat ma'sum hanya pada diri Ahli Kisa saja yaitu: Ali, Fathimah, Hasan dan Husein, dan sifat ma'shum ti dak bersifat mutlak (absolut). Jadi kema'shuman ti dak berkaitan dengan sikap lalai, salah dan lupa sebagaimana halnya pandangan Syiah Imamiyah dan Syiah Isma'iliyah-. Dan selain perkara syari'at, seperti perkara fatwa, permasalahan politi k serta sosial, sifat kema'shuman yang dimiliki oleh seorang Imam bukan suatu kewajiban untuk mengikuti semua ti ndakan-ti ndakan mereka ${ }^{28}$.

Pendapat ini ditegaskan oleh salah seorang ulama Syiah Zaidiyah bernama Imam Ahmad bin Yahya al-Murtadha yang memiliki pandangan yang saling berbeda, pada kitab "al-Durar al-Faraaid" ia mengatakan bahwa sifat 'ishmah ditujukan kepada Ahli Kisa, yaitu Imam Muhammad, Ali, Fatimah, Hasan dan Husein, dengan dasar dalil firman Allah swt.:

${ }^{28}$ Lih, Abdullah bin Muhammad Hamiduddin, az-Zaydiyah, hal 122. 



Terjemahnya:

dan hendaklah kamu tetap di rumahmu dan janganlah kamu berhias dan bertingkah laku seperti orang-orang Jahiliyah yang dahulu dan dirikanlah shalat, tunaikanlah zakat dan taatilah Allah dan Rasul-Nya. Sesungguhnya Allah bermaksud hendak menghilangkan dosa dari kamu, Hai ahlul bait dan membersihkan kamu sebersih-bersihnya.

Dan dilalah ayat ini adalah sebagaimana berikut:

1. Ini adalah ayat yang bersifat pasti (qath'i) dan tidak boleh diingkari.

2. Sesungguhnya yang dimaksud dengan ar-rijs (dosa) di dalam ayat ini adalah berbagai kesalahan. Karena ar-rijs menurut pengerti an bahasa adalah ibarat benda-benda yang kotor dan buruk. Dan yang dimaksudkan dengan ayat ini hanyalah makna ini saja. Maka kalau begitu, sudah pasti sifat ma'shum mereka itu dari berbagai kesalahan.

3. Yang dimaksud dengan ahlul bait adalah Ali, Hasan, dan Husein.

4. Sesungguhnya ketiga orang Imam ini wajib memiliki sifat ma'shum, karena bagi setiap satu dari ketiga Imam ini memiliki dalil yang tersendiri ${ }^{29}$.

Pada tempat lain seorang ulama Syiah Zaidiyah bernama al-Shahib Ibnu 'Ubbad menjelaskan tentang hakikat perbedaan pandangan sebahagian Syiah Zaidiyah tentang 'ishmah dengan Syiah Imamiyah dan Syiah Isma'iliyah, dia menjelaskan bahwa kema'shuman imam dalam pandangan Syiah Zaidiyah ti dak sama dengan kema'shuman Rasulullah yang bersifat mutlak (absolut) dan terpecaya sepenuhnya, yaitu dapat terhindar dari segala-galanya, seperti sifat lalai dan lupa ${ }^{30}$.

Dengan demikian dapat dikatakan bahwa mayoritas Syiah Zaidiyah tidak menjadikan sifat ma'sum bagi seluruh imam, dan kema'suman yang mutlak

${ }^{29}$ Lihat, Ahmad bin Yahya al-Murtadha, ad-Durr al-Fara id, waraqah 194, Ba` jim jilid 2, manuskrip di Maktabah al-Jaami' al-Kabir, Shan'a, dinukil dari Muhammad Hasan al-Kamali, al-Imam al-Mahdi Ahmad bin Yahya al-Murtadha wa Atsaruhu Fi al-Fikr al-Islami, hal 463.

${ }^{30}$ Ash-Shahib bin Ubbad, az-Zaydiyah, hal 185. 
sebenarnya hanyalah bagi diri Nabi Muhammad saw.

Tentunya pandangan ini sangat berbeda dengan pandangan teologi Syiah Imamiyah dan Syiah Isma'iliyah yang mengatakan bahwa keseluruhan imamImam Syiah adalah suci (ma'sum) dari segala perbuatan dosa kecil ataupun besar, baik yang tersurat ataupun yang tersirat, sengaja atau ti dak disengaja. Di samping itu mereka harus terbebas dari kesalahan bahkan dari kelupaan dan kelalaian.

\section{Keempat: Keabsahan Pemimpin}

Syiah Zaidiyah mensyaratkan keabsahan seorang Imam melalui revolusi (al-Khuruj) atau boleh kita isti lahkan"revolusi pedang". Revolusi ini melambangkan perjuangan kepemimpinan Syiah Zaidiyah dengan ketegaran dan ketegasan serta penuh keterbukaan.

Berbeda dengan aliran Syiah Imamiyah dan Syiah Ismaíliyah, di mana perjuangan mereka dengan cara tersembunyi dan terselubung, atau dikenal dengan konsep (Taqiyyah).

Dengan konsep dan sistem revolusi ini, Syiáh Zaidiyah tidak menjadikan Imam Ali bin al-Husein alias Zainal Abidin (kakek imam Zeid) masuk dalam rangkaian imam. Sementara Syiáh Imamiyah dan Syiah Ismaílyah menjadikan Ali bin al-Husein sebagai bagian dari silsilah imam mereka.

Konsep revolusi ini telah dirumuskan sendiri oleh Imam Zaid, dan sekaligus diaplikasikan dalam periode kepemimpinannya untuk memberontak terhadap keti dak adilan yang berlaku. Maka ia melancarkan revolusi politik terhadap penguasa ketika itu, meskipun tindakan revolusi tersebut tidak mendapatkan dukungan dari pihak keluarganya, seperti saudara kandungnya Muhammad Baqir, dan Muhammad bin al-Hanafiah. Kedua-duanya menasehati Imam Zaid mengenai bahaya yang akan dihadapinya bila ia meneruskan revolusi tersebut. Namun ia menolak nasehat tersebut, dan pergi ke luar untuk memberikan contoh kepada orang-orang yang ada di sekelilingnya.

Tindakan ini mendapatkan reaksi berat dari Syiáh Imamiyah dan Syiáh Ismíliyah. Lalu mereka mengkriti si segala bentuk tindakan revolusi yang dilakukan oleh para pengikut Imam Zaid setelah kemati annya.

Dapat dilihat, bahwa sikap revolusioner yang dilakukan oleh aliran Syiáh Zaidiyah dengan sendirinya menunjukkan bahwa seorang pemimpin atau kepaa negara bukannya orang yang suci (Ma'shum) dan layak dikultuskan, yang tidak terlepas dari kesalahan dan dosa.

Sementara bagi Syiáh Imamiyah dan Syiáh Ismaíliyah malah sebaliknya, imam adalah simbol kesucian (Ma'shum). Maka sistem kepemimpinan politik 
dan pemerintahan mereka dikenal dengan sistem Teokratis. Dan sistem ini telah dikenal sejak zaman mesir kuno, Yunani dan Rumania. Di mana seorang pemimpin negara dimata rakyat merupakan simbol agama dan dunia sekaligus. Oleh karena itu, bentuk pemerintahan dibungkus dengan keagamaan yang tercetak dalam diri seorang raja. Ia dijadikan sebagai kekuasaan absolut yang tidak boleh dipertanyakan dalam bentuk apa pun. Tidak peduli apakah raja tersebut berlaku adil ataupun tidak. Apakah dia bijak, baik atau jahat. Kesemuanya tidak menjadi masalah, sebab keputusan yang dibuatnya menurut asumsi mereka adalah keputusan Ilahi semata. Dan konsep tersebut diadopsi oleh beberapa sistem pemerintahan yang mengaku diri Islam, dalam istilah yang dikenal dengan sistem "Teokrasi”. Padahal agama Islam sendiri ti dak demikian sistemnya, sebagaimana yang dijelaskan dalam fi rman Allah swt.:

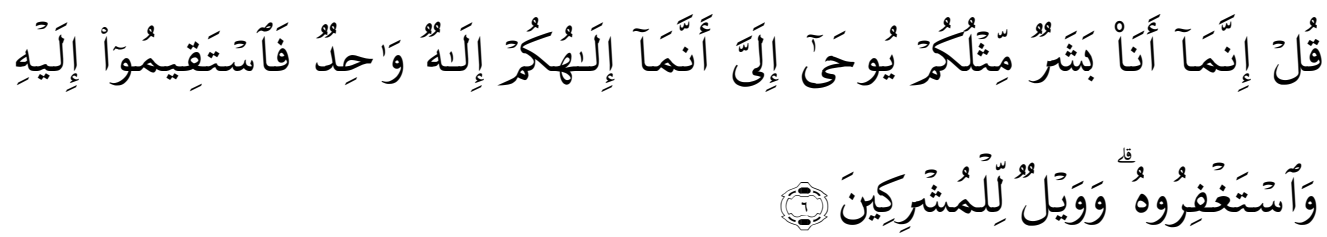

Terjemahnya:

"Bahwasanya aku hanyalah seorang manusia seperti kamu, diwahyukan kepadaku bahwasanya Tuhan kamu adalah Tuhan yang Maha Esa, Maka tetaplah pada jalan yang Lurus menuju kepadanya dan mohonlah ampun kepadanya. dan kecelakaan besarlah bagi orang-orang yang mempersekutukan-Nya. (Fushshilat: 6).

Namun sangat disayangkan, penetrasi sistem Teokrasi ini lebih dalam daripa da penetrasi sistem agama Islam. Dari uraian diatas nampak jelas keunikan system kepimimpinan politik Syiáh Zaidiyah dibandingkan aliran Syiáh Imamiyah dan Syiah Ismaíliyah. Di mana pengangkatan seorang imam dilakukan dengan jalan suksesi, yang dalam era politik sekarang dikenal dengan sistem "demokrasi", yang dilandaskan atas konsep revolusi (al-Khuruj). Hal ini yang memoti vasi Syíah Zaidiyah menolak "Taqiyyah," yaitu perinsip perjuangan politi k Syiáh Imamiyah dan Syi”ah Ismailiyah yang terselubung dan sembunyi.

\section{F. Kepemimpinan Kontemporer Syiah "Wilayah al-Faqih"}

Saat ini kelanjutan dari konsep imamah dikenal dengan "Wilayah alFaqih", ia merupakan konsep terbaru dari golongan Syiah Imamiyah di Iran, sebagai alternatif dari Imam al-Gha'ibah, konsep ini dibuat sebagai respon dari 
berbagai pertanyaan-pertanyaan yang diajukan oleh ulama Ahlu Sunnah terhadap ulama Syiah Imamiyah. Sebab salah satu ajaran asas dalam Syiah adalah mengakui adanya Imam pada seti ap masa, yang tugasnya memecahkan segala persoalan umat, namun karena imam tersebut ti dak muncul hingga saat ini, jadi siapakah yang bertanggung jawab atas segala persoalan-persoalan umat?. Untuk merespon teka-teki ini maka Syiah Imamiyah di Iran membuat sistem kepemimpinan modern iaitu "Wilayah al-Faqih" iaitu pemerintahan yang dikendalikan oleh seorang Fakih, memiliki sifat adil dan pandai dalam masalahmasalah agama. Dengan demikian kepemimpinan ini sebagai kepemimpinan alternati f pada masa keti adaan seorang imam (Ghaibatul Imam), al-faqih adalah seorang mujtahid yeng memenuhi semua persyaratan untuk menjadi wakil imam yang menghilang atau ghaib. Dan sangmujtahid ini tampil menjadi hakim dan pemimpin.

Istilah Wilayah dalam kamus bahasa Arab berasal dari akar kata: "wali, walayah, dan mawla". wali merujuk pada tiga makna: teman, setia/ berbakti , dan Pendukung atau Penyokong. Sedangkan Wilayah memiliki dua makna yaitu: (1) kekuasaan (terti nggi) dan penguasaan, (2) kepemimpinan dan pemerintahan ${ }^{31}$.

Selanjutnya kata (al-Faqih) secara bahasa berarti orang yang memiliki pengetahuan mendalam dan mencapai ti ngkat tertentu dalam ilmu dan kesalehan sehingga mampu berijtihad ${ }^{32}$. Zaman sekarang ini dikenal sebagai Ahli hukum Islam. Dengam demikian kepemipinan ini dapat disebut sebagai kepemimipinan dan pemerintahan ulama.

Konsep tersebut di perkenalkan oleh Ayatullah Khumeini dengan perancangan yang sedemikian rupa untuk mendirikan sebuah negara Islam yang berasaskan ideology Syiah Imamiyah dengan nama "Islamic Republic of Iran". Ayatullah Khomeini merupakan fakih pertama dalam sejarah kepemimpinan Wilayatul Fakih. Dan setelah diterimanaya konstitusi iran melalui referendum 1 dan 2 pada bulan Desember 1979 negara Iran kemudian melangkah menuju normalisasi kehidupan politik berlandaskan Syiah sampai sekarang. Yang sebelumnya merupakan negara di bawah kepemimpinan Syah Iran yang bergelar Raja Diraja (Syahansyah) Mohammad Reza Pahlevi.

Berkaitan dengan teori Wilayah al-Faqih ini, sebenarnya Syiah Imamiyah sendiri berbeda pendapat tentang kewujudannya. Dalam artian sebagian ulama Syiah tidak mengakui keabsahan kepemimpinan tersebut, seperti syeikh Murtaza al-Ansori dan syeikh al-Sayyid al-Khuu'i, kedua ulama Syiah ini terkenal keras

\footnotetext{
31 Al-Azhari, Tahzibullughah, $1 / 204 .$.

32 Al-Jurjani, al-Ta'rifat, 23, Darul Kutub al-Arabi, Beirut-Lebanon, 1405 H.
} 
menantang, menolak dan mengingkari Wilayah al-Faqih. Dan justeru mereka sangat loyal menunggu dan menantikan kehadiran imam ghaib.

Oleh karena itu ada hal yang menarik untuk dicermati bahwa sebenarnya penubuhan konsep tersebut secara tidak langsung merupakan bentuk kritikan terhadap konsep Imam al-Mahdi al-Muntazar ${ }^{33}$. Sebab peranan imam Ma'sum yang ghaib ini tidaklah mudah dan sangat esensial, iaitu: menegakkan hudud dan memungut zakat. Bahkan yang sangat bermasalah lagi kalau sebagian penganut aliran Syiah Imamiyah merasa tidak wajib melaksanakan solat jum'at karena ketidak hadiran imam al-Ghaib al-Muntazar. Jadi hal inilah yang dikhawatirkan oleh Imam Khumaini sehingga membela matimati an konsep "Wilayah al-Faqih" dalam berbagai buku karyanya, dan khususnya "al-Hukumah al-Islamiyah".

Mengenai konsep Wilayat al-Faqih, Musa al-Muwasawi memberikan catatan dalam Risalah at-Tashihiyyah yang layak untuk diperhati kan: "wilayah faqih adalah sayap atau bid'ah yang kedua yang ditambahkan kepada kekuasaan agama, yang mengklaim bahwa mereka adalah para wakil Imam Mahdi pada masa keghaiban panjang. Ide pemikiran ini pada makna yang detail merupakan ide pemikiran reinkarnasi yang berasal dari pemikiran Kristen yang masuk ke dalam pemikiran Islam, yang isinya bahwa Allah merasuk ke dalam tubuh alMasih, dan al-Masih merasuk ke dalam tubuh paderi yang paling agung. Dan pada era kekuasaan gereja di Sepanyol, Italia, dan sebagian Perancis, memberikan hukuman kepada orang-orang Kristen dan yang lainnya dengan nama kekuasaan tuhan mutlak. Dan bid'ah ini telah menyusup ke dalam pemikiran Syiah setelah berlakunya keghaiban panjang. Dan mengambil porsi dalam akidah ketika para ulama Syiah mengadopsinya ke dalam imamah, dan mengatakan bahwa imamah adalah posisi ilahi sebagai penerus Rasulullah saw. Dan karena imam dalam keadaan hidup, akan tetapi dia dighaibkan pada masa penantian, dan kekuasaan ilahi tidak hilang dengan sebab keghaiban imam, maka kekuasaan ini berpindah dari sang imam ghaib kepada para wakilnya, karena wakil menempati posisi yang dia wakili pada segala sesuatu" ${ }^{34}$.

Fungsi Kepemimpinan Wilayatul Faqih masih dalam kerangka kepemimpinan klasikia itu imamah. Melihat pada kontinuitas kepemimpinan ilahiah, yang melalui jalur kenabian, kemudian dilanjutkan melalui garis imamah, dan juga ulama (faqih), maka fungsi kepemimpinan mencakup empat hal yaitu berfungsi sebagai: legislative (menerangkan hukum), yudikatif (memutuskan

${ }^{33}$ Lebih jelas lihat: Kamaluddin Nurdin, Imam Mahdi -Kajian Perbandingan Sunni \& Syiah-, Pts, Malaysia, 2016.

${ }^{34}$ Musa al-Mawsuy, asy-Syi'ah wat-Tasyayyu', hal 70. 
hukum), eksekutif (mengatur masyarakat) dan edukatif (mendidik umat).

Di antara tugas wali faqih yang merupakan pilar utama pemerintahan dan sebagai pememipin angkatan bersenjata, makaia berhak memutuskan apakah suatu konstitusi yang dikonsepsikan sesuai atau tidak dengan hukum Islam. Keputusan akhir bagi hukum-hukum sosial yang berada ditangan dan kekuasaanya. Kalau ada terdapat perbedaan terhadap poinpoin di atas, maka wali al-faqih menunjuk hakim pengadilan untuk memutuskan isu-isu tersebut. Ia mendirikan lembaga-lembaga peradilan di seluruh propinsi dan daerah untuk mendengar, memutuskn kasus-kasus dan untuk memelihara kepentingankepentingan dari partai-partai yang dirugikan.

Di samping itu, kekuasaan wali faqih memeliki kewenangan yang absolut dan nyaris tidak terbatas, sebab ia menjadi mendataris resmi nabi dan para imam as. terutama Imam Mahdi. Imam Khumaini, peletak sistematis konsep wilayah al-faqih menegaskan bahwa kewenangan seorang fakih yang adil sama dengan wilayah nabi saaw. dan para imam. meskipun kedudukan (maqam) nabi dan imam jelas tidak sama dengan maqamnya para fakih. Namun, yang menjadi dasar pikir kewenangan fakih adalah fungsinya bukan kedudukannya (maqam).

\section{G. Dasar-Dasar Konsep Kepemimpinan Ahli Sunnah}

Kepemimpinan Ahli Sunnah memiliki nilai-nilai kepemimpinan yang transformatif dan efektif berdasarkan sejarah pemilihan kepemimpinan yang diamalkan pada zaman Khulafaurrasyidin.

Secara garis besar, konsep kepemimpinan Ahlu Sunnah didasari oleh tiga hal, yaitu dengan cara pemilihan (ikhtiar/inti khab) yang dibangun di atas syuraa, ijma' dan bai'at. Kemudian dalam prose pemilihan pemimpin melalui tiga cara, iaitu:

1. Pemilihan dengan musyawarah (Musyawarah menjadi salah satu nilai kepemimpinan dalam politik Islam yang tertuang dalam Qur'an.

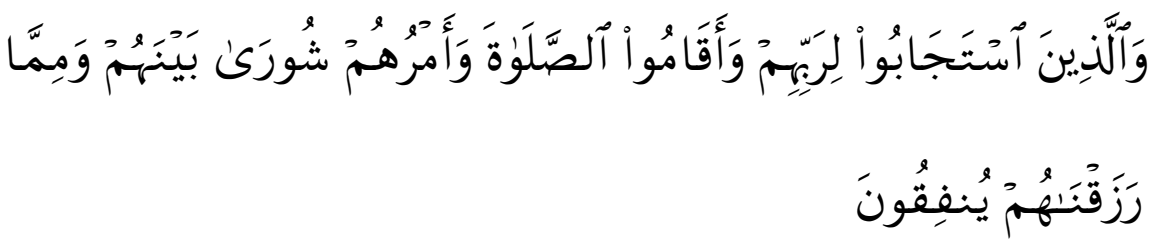

Terjemahnya:

dan (bagi) orang-orang yang menerima (mematuhi) seruan Tuhannya dan 
mendirikan shalat, sedang urusan mereka (diputuskan) dengan musyawarat antara mereka; dan mereka menafkahkan sebagian dari rezki yang Kami berikan kepada mereka. (As-Syura: 38).

Pemilihan secara musyawarah ini telah diterapkan pada masa dua khalifah iaitu Abu Bakar dan Ustman. Tentunya konteks ini secara tidak langsung merupakan indikasi bahwa cara syurah dalam menentukan kepemimimpinan Islam tidak menafi kan nilai-nilai demokrasi serta menerapkan sebuah kepemimpinan yang transformatif.

2. Penunjukan (ال تع يـ ين). Hal ini diterjemahkan oleh para ulama dari bacaan sejarah secara normatif, dimana Abu bakar menunjuk langsung penerus kepemimpinan kepada Umar sebagai khalifah. Hal ini juga dilakukan oleh para khalifah dinasti Umayyah dan Abbasiyah terhadap para penggantinya. Namun dalam perkembangannya cara ini tidak begitu efektif dalam kepemimpinan Islam, sehingga dimanfaatkan oleh para khalifah-khalifah selanjutnya untuk mempertahankan kekuasaan untuk para anak cucunya yang dikenal sebagai pemerintahan monarki.

3. Ikrar kesetiaan/sumpah jabatan (ال بـ بـعة). Baiat menjadi ciri pengangkatan kepemimpinan Islam karena dengan adanya bai'at, maka terjadi sumpah setia antara kedua belah pihak pemimpinan dan masyarakat, pemimpin bersumpah setia akan melaksanakan tugasnya dengan baik serta mengutamakan kepentingan masayarakat, bangsa, negara dan agama dari kepentingan pribadi dan golongan. Sementara rakyat berjanji untuk mentaati pemimpin selama pemimpin tidak keluar dari rambu-rambu syari'at Islam. Baiat ini akan mengarah kepada kepemimpinan yang efektif.

"Wahai manusia sekalian sesungguhnya aku telah dipilih sebagai pimpinan atas kalian dan bukanlah aku orang yang terbaik diantara kalian maka jika berbuat kebaikan bantulah aku. Jika aku berti ndak keliru maka luruskanlah aku, kejujuran adalah amanah dan kedustaan adalah khianat. Orang yang lemah diantara kalian ia kuanggap kuat hingga aku mengembalikan haknya kepadanya jika Allah menghendaki.

Sebaliknya yang kuat diantara kalian aku anggap lemah hingga aku mengambil darinya hak milik orang lain yang diambilnya jika Allah mengehendaki. Tidaklah suatu kaum meninggalkan jihad di jalan Allah kecuali Allah timpakan kehinaan dan tidaklah kekejian tersebar di suatu kaum kecuali adzab Allah diti mpakan kepada kaum tersebut. Taatilah aku selama aku taat 
kepada Allah dan RasulNya. Tetapi jika aku tidak mentaati Allah dan RasulNya maka tiada kewajiban untuk taat kepadaku"35.

\section{H. Imamah Bukan Rukun Agama Islam}

Dalam teologi Ahlu Sunnah rukun Islam ada lima: Dua kalimat syahadat, solat, zakat, haji dan puasa. Urgensi bersatunya kelima rukun Islam untuk masuk dalam defi nisi seorang Muslim nampak dalam hadits Nabi saw yang diriwayatkan dari Abu Abdurrahman Abdullah bin Umar bin al-Khaththab, yang teksnya adalah:

Artinya:

Aku mendengar Rasulullah saw bersabda: "Islam dibina berdasarkan lima perkara: syahadah bahwa ti dak ada tuhan selain Allah dan sesungguhnya Muhammad adalah utusan Allah, mendirikan shalat, mengeluarkan zakat, melaksanakan ibadah haji ke Baitullah, dan berpuasa di bulan ramadhan" (HR. Bukhari dan Muslim).

Sedangakan rukun iman ada lima: kepercayaan kepada Allah swt., para Malaikat, Kitab-kitab, para Rasul, hari kiamat, Qadha dan Qadar (takdir). Sebagaimana hadis Ibnu Umar. Ra:

"Iman adalah, percaya dan meyakini wujud Allah swt., para Malaikat, para Rasul, hari kiamat, Qadha dan Qadar (takdir)”. (Muslim, no: 9).

Oleh karena dalaam teologi Ahli Sunnah imamah tiada kaitan sama sekali dengan rukum Islam dan rukun Iman sebagaimana yang diyakini oleh Syiah.

Imam al-Ghazali berkata: "sesungguhnya teori imam bukanlah perkara yang penti ng. Juga ti dak termasuk sebagai seni rasional. Bahkan imamah adalah perkara fiqhiyyah. Dan nazhariyyah terbagi kepada dua bagian: satu bagian yang berkaitan asal kaidah, dan satu bagian yang berkaitan dengan furu'. Sedangkan ushul iman ada tiga: keimanan kepada Allah, kepada Rasul-Nya, dan hari akhir. Dan yang selainnya adalah furu" 36 .

Imam al-Juwaini berkata: "sesungguhnya imamah tidak termasuk ke dalam dasar akidah" 37 . Sedangkan al-Iji (pengarang kitab al-Mawaqif) berkata: "sesungguhnya imamah tidak termasuk ke dalam dasar agama dan akidah, berbeda dengan Syiah. Bahkan bagi kami dia adalah masuk ke dalam furu' yang

\footnotetext{
${ }^{35}$ Ibnu Hisyam, 6/82, Darul Jail Beirut-Lebanon, $1411 \mathrm{H}$.

36 Al-Ghazali, al-Iqti shad Fi al-I'ti qad, hal 134, cet Shubaih, Kairo.

${ }^{37}$ Al-Juwaini, al-Irsyad, hal 10, cet Kairo, 1950 M.
} 
berkaitan dengan perbuatan orangorang mukallaf' ${ }^{38}$.

Ibnu Khaldun juga menegaskan, bahwa imamah bukanlah sebuah perkara yang penti ng. Karena imamah masuk ke dalam bagian maslahat umum yang diserahkan kepada semua kaum muslimin. Dan Rasulullah saw. tidak menentukan khalifah dalam imamah ${ }^{39}$.

Inilah pandangan aliran Ahlu Sunnah mengenai imamah, bahwa dia bukan salah satu rukun agama, juga bukan salah satu dasar agama. Dan sesungguhnya imamah adalah salah satu cabang agama, yang tidak berkaitan dengan akidah keimanan.

Dengan demikian, konsep kepimimpinan Sunni berbeda dengan konsep kepemimpinan Syiah yang hanya melalui proses penentuan/penunjukan yaitu pemilihan imam (pemimpin) langsung dari Allah swt melalui Nabi saw. Sehingga Implikasi dari konsep kepemimpinan seperti ini, menjadikan imam-imam mereka terlepas dari kesalahan (maksum) dan apa yang ditetapkan oleh imamnya tidak boleh dibantah, ditentang dan dilawan karena dianggap sebagai wahyu.

\section{Penilaian Imam Qurtubi Terhadap Hadits “ Man Kuntu Maulaahu”}

Terdapat beberapa hadits yang dijadikan dalil oleh syi'ah mengenai kewujudan penentuan "nash" kepimpinan bagi Ali ra, sehingga umat islam dianggap sesat dan kafir atas pengingkarannya terhadap nash tersebut, sebab mereka telah melanggar perintah dan keputusan Rasulullah saw. Hadits tersebut adalah:

Artinya:

"Barang siapa yang menjadikan aku sebagai walinya maka Ali adalah juga walinya. Ya Allah, belalah orang yang membelanya, dan perangilah orang yang memeranginya".

Mereka berkata: lafadz "al-mawla" di dalam bahasa arab memiliki makna "Aula", yaitu: paling utama, manakala beliau bersabda "maka Ali juga menjadi walinya" dengan fa ta'qib, maka diketahui bahwa yang dimaksud dengan perkataan "mawla" adalah paling berhak dan paling utama. Jika demikian berarti maksud Nabi adalah kepimpinan "imamah" yang harus ditaati.

Imam al-Qurtubi menjawab penafsiran tersebut dengan beberapa hal:

1. Ini bukanlah hadits mutawatir. Dan kesahihannya telah diperdebatkan. Abu Daud as-Sajastani dan Abu Hati m al-Razi telah mengkritik hadits

\footnotetext{
38 Al-Iji, Kitab al-Mawaqif, 3/578

${ }^{39}$ Ibnu Khaldun, al-Muqaddimah, hal 19.
} 
ini, dan membantahnya dengan hadits lain yaitu: $\dot{0}$

Artinya: "Muzayyanah, Juhainah, Ghiffar, dan Aslam, mereka tidak mempunyai wali selain Allah dan Rasul-Nya". Jika memang benar Nabi saw telah bersabda: "barang siapa yang menjadikan aku sebagai walinya, maka Ali juga menjadi walinya", berarti salah satu dari kedua hadits di atas adalah dusta.

2. Sesungguhnya hadits tersebut jika benar (sahih), kerana diriwayatkan oleh para perawi yang terpercaya, akan tetapi di dalamnya tidak ada yang menginsyaratkan kepimpinan bagi Ali, melainkan isyarat yang ada hanyalah tentang kemuliaan Ali. Karena al-Mawla memiliki makna wali, jadi makna hadits: 'barang siapa yang menjadikan aku sebagai walinya maka Ali juga menjadi walinya". Jadi maksud hadits ini adalah agar manusia mengetahui bahwa zahirnya Ali sama dengan batinnya. Dan itu adalah suatu kemuliaan yang besar bagi Ali.

3. Sesungguhnya hadits ini muncul berdasarkan suatu sebab tertentu (Asbabl Wurud) ${ }^{40}$, yaitu manakala Usamah dan Ali berselisih faham, maka Ali berkata kepada Usamah: "kamu maulaku", dan Usamah menjawab: "aku bukan maula kamu; akan tetapi aku adalah mawla Rasulullah saw.”. Maka perkara tersebut dilaporkan kepada Nabi saw., dan beliau bersabda: "barang siapa yang menjadikan aku sebagai walinya maka Ali juga adalah walinya".

Sabda Rasulullah saw untuk Ali: "kedudukan kamu bagiku sama dengan kedudukan Harun bagi Musa, akan tetapi tidak ada nabi setelahku". Dalam hadits ini, Rasullah mengumpamakan kedudukan Ali disisinya seperti kedudukan Nabi Harun di sisi Nabi Musa, jadi ini memberikan makna dan isyarat bahawa Ali adalah sebagai khalifah setelahnya.

Imam al-Qurtubi mengomentari hadits di atas bahwa ulama sepakat tentang makna hadits, yaitu ucapan Nabi bukan bertujuan bahawa Nabi Harun menjadi khalifah setelah Nabi Musa, di samping itu Nabi Harun meninggal dunia sebelum Nabi Musa. Jika yangbeliau maksudkan dengan perkataanya: "posisi kamu bagiku sama dengan posisi Nabi Harun bagi Nabi Musa" adalah khilafah, maka beliau pasti berkata: posisi kamu bagiku sama dengan posisi Yusya' bagi Nabi Musa. Dan manakala beliau tidak berkata seperti itu berarti menunjukkan bahwa bukan khilafah yang beliau maksudkan, akan tetapi yang beliau maksudkan adalah: "sesungguhnya aku menyerahkan tanggung jawab kepadamu

40 Asbab Wurud al-Hadits, adalah sebab atau latar belakang hadits keluar dari lisan Rasulullah saw. 
TRANSFORMASI: Jurnal Kepemimpinan Dan Pendidikan Islam

Volume: 3 Nomor 2 Juni 2020

Rekognisi Kebijakan Pemerintah Terhadap Pesantren ...., H. 28-41

Muh. Mustakim

mengenai keluargaku keti ka aku masih hidup, dan keti ka aku telah ti ada" ${ }^{\prime 1}$.

\section{PENUTUP}

Keberbagaian aliran Syiah dapat dibatasi kepada tiga golongan yang masih eksis sampai saat ini, yaitu Syiah Zaidiyah, Syiah Imamiyah dan Syiah Isma'iliyah. Dan Syiah Zaidiyah didirikan oleh Imam Zaid, sedangkan Syiah Imamiyah yang memiliki karakteristik yang berupa pengakuan mengenai kepemimpinan dua belas imam yang didirikan oleh Musa bin Ja'far (al-Kadzim) sebagai imam yang ketujuh dari urutan kepemimpinan. Di samping itu golongan ini juga diberikan julukan al-Ja'fariyah, karena berbagai pandangan fiqh mereka bersandarkan kepada pendapat imam Ja'far ash-Shadiq. Adapun Syiah Isma'iliyah didirikan oleh Isma'il bin Ja'far, golongan ini sebenarnya adalah bentuk perpanjangan golongan ekstrimis Syiah (Ghulat) dan dikenal dengan Syiah Bathiniyah. Penamaan Syiah Isma'iliyah terus melekat sampai berdirinya dinasti Fathimiah pada tahun 296 H. Maka pada masa tersebut nama Isma’iliyah diganti dengan nama baru, yaitu "al-Fathimiah". Kemudian, nama Isma'iliyah kembali dipergunakan setelah dinasti Fathimiah mengalami kehancuran pada tahun 566 H. Dan pada masa peperangan salib, kelompok Syiah Isma’iliyah ini terkenal dengan julukan "al-Hasysyasyin" atau "Assassins". Dari pemaparan tulisan ini dapat diambil sebuah kesimpulan umum bahwa perselisihan di dalam tubuh Syiah tidak hanya terbatas pada jumlah imam dan penetapan individu imam saja, akan tetapi mereka juga berselisih pendapat mengenai tugas sang imam, yaitu sebagaimana berikut ini:

- Sesungguhnya syarat keabsahan dan kesahihan diakuinya seseorang sebagai pengikut Syiah adalah keyakinannya bahwa kepemimpinan politik "imamah" adalah salah satu dasar agama. Dan dapat dilihat bahwa perselisihan yang terjadi di antara Sunnah dan Syiah terbentuk hanya berdasarkan motif politi $\mathrm{k}$ saja. Oleh karena itu, maka imamah adalah point utama yang memecah belah kaum muslimin kepada kelompok Sunnah dan Syiah.

- Imamah dalam pandangan Syiah Zaidiyah secara general tidak sama dengan pandangan Syiah Imamiyah dan Syiah Isma'iliyah yang telah mengangkat imamah kepada tingkatan kenabian, atau kepada tingkatan yang mendekati tingkatan kenabian. Karena mereka mengqiyaskan para imam kepada para nabi. Dan yang membedakan imam dengan Nabi menurut pandangan

${ }^{41}$ Al-Qurtubi, al-Jami’ li-Ahkam al-Qur`an, 1/184. 
mereka adalah, tidak diturunkan wahyu kepada imam. Sedangkan Syiah Zaidiyah menganggap imam adalah manusia sebagaimana halnya manusia yang lain, dan tidak memiliki kelebihan dari manusia biasa. Oleh karena itu, Syiah Zaidiyah mengkritik pandangan Syiah Imamiah dan Syiah Isma'iliah Bathiniah yang menyamakan kedudukan imam sederajat dengan kedudukan Nabi. Dan Syiah Zaidiyah berpendapat bahwa tidak boleh meng-qiyaskan kepemimpinan (imamah) kepada kenabian. Karena Allah swt. telah mengkhususkan para nabi-Nya dengan mu'jizat, maka Dia muliakan mereka dengan mu'jizat yang tidak dimiliki oleh manusia yang lain.

- Semua aliran-aliran Syiah baik Zaidiyah, Imamiyah, dan Isma'iliyahbersepakat mengenai kewajiban imamah berlandaskan penentuan Nash dan penunjukkan langsung dari Nabi. Dan mereka sepakat bahwa kepemimpinan (imamah) tiga imam: Ali bin Abi Thalib, Hasan, dan Husein, telah ditentukan secara "nash". Namun penentuan "nash" untuk kepemimpinan Imam Ali menurut Syiah Zaidiyah -kecuali Imam Humaidan bin Yahya bersifat khafi (samar). Adapaun Nash untuk kepemimpinan Hasan dan Husein adalah Nash jaliyy (jelas). Dan kepemimpinan para imam yang setelah ti ga imam ini tidak ditentukan nashnya, karena kepemimpinan mereka ditentukan dengan cara dakwah (melakukan revolusi). Maka seseorang tidak dapat menjadi imam dengan hanya sekedar terkumpul di dalam dirinya berbagai syarat yang telah ditetapkan oleh golongan ini. Akan tetapi, dia harus melakukan dakwah, atau keluar memploklamirkan dirinya sebagai imam, dan memerangi kezaliman. Dan patut diberikan catatan, bahwa ash-Shalihiyah yang merupakan sempalan Syiah Zaidiyah mempunyai pendapat yang dekat dengan Ahlu Sunnah dalam masalah ini. Karena mereka berpendapat bahwa jalan untuk menentukan kepemimpinan setelah kemati an imam Ali, Hasan, dan Husein adalah dilakukan dengan cara musyawarat dan pemilihan.

- Syiah Imamiyah berpendapat bahwa kepemimpinan semua imam yang terdiri dari dua belas imam telah ditentukan secaran "nash jaliyy (teks jelas). Namun kedudukan imam yang di-nash-kan kepemimpinannya dan kemudian menghilang (ghaib) maka diganti kan dengan seorang mujtahid yang memenuhi syarat, sebagai wakil sang imam pada masa hilangnya (keghaibannya). Dan dia adalah hakim atau presiden mutlak. Sedangkan Syiah Isma'iliyah berpendapat lain bahwa kepemimpinan para imam mereka telah ditentukan "nash-nya". Dimulai dari Ali bin Abi Thalib sampai munculnya "sang penegak keadilan", yaitu Muhammad bin Isma'il. Di 
samping itu, Syiah Imamaiyah dan Syiah Isma'iliyah sepakat bahwa kepemimpinan terbatas hanya kepada keturunan Husein saja. Sedangkan Syiah Zaidiyah menjadikannya milik keturunan Hasan dan Husein tanpa ada perbedaan.

- Syiah Imamiyah dan Syiah Isma'iliyah membatasi posisi kepemimpinan politi k (imamah) hanya untuk keturunan Husein saja adalah dikarenakan mundurnya Imam Hasan dari jabatan sebagai khalifah keti ka itu, dan menyerahkannya kepada Mu'awiyah bin Abi Sufyan. Dari peristi wa ini, Syiah Isma'iliyah mereka-reka teori baru dalam kepemimpinan yaitu imam mustaqarr (permanen) dan imam mustawda' (imam sementara). Jika Syiah berpendapat bahwa imam setelah Nabi saw adalah Ali bin Abi Thalib, maka bagaimana sikap mereka terhadap ti ga khualafa urrasyidun Abu Bakar, Umar, dan Utsman-, serta sahabat yang lainnya? Syiah Imamiyah dan Syiah Isma'iliyah sepakat mengatakan bahwa mereka telah melakukan kesalahan, dan menyalahi wasiat Nabi saw. Dan mereka berpendapat bahwa para sahabat ini adalah para pendusta, pengkhianat, dan kafi r. Sedangkan mayoritas Syiah Zaidiyah bersikap penuh toleransi dan kerelaan atas kepemimpinan mereka. Oleh karena itu, mereka kriti k tindakan pencercaan Syiah Imamiyah dan Syiah Isma'iliyah terhadap para sahabat. Dan mereka tegaskan bahwa pembai'atan mereka (khualafa urrasyidun) bukanlah suatu kesalahan selama Ali meninggalkan haknya secara suka rela dan tidak menuntut. Oleh karena itu, sesiapapun juga tidak boleh memfasikkan mereka, terlebih lagi mengkafirkan mereka.

- Respon Ahlu Sunnah terhadap masalah penentuan dan pelanti kan imam dengan nash dan wasiat Nabi Saw. Ahli Sunnah berpendapat bahwa haditshadits yang diklaim oleh Syiah sebagai nash bagi kepemimpinan Imam Ali bin Abi Thalib telah ditolak dan dibatalkan oleh kesepakatan ulama Islam pada masa permulaan. Karena semua umat Islam tunduk di bawah kepemimpinan Abu Bakar dan Umar ra, serta mengakui kewajiban untuk mentaatinya, dan bersatu di bawah kepemimpinan keduanya. Di antara mereka itu adalah Ali, Abbas, Ammar bin Yasir, Miqdad, Abu Dzarr, Zubair bin Awwam, serta semua orang yang mengkalim bahwa dia memiliki dan meriwayatkan nash imamah. Sedangkan hadits yang dijadikan dalil oleh Syiah yang berbunyi: "Barang siapa yang menjadikan aku sebagai walinya, maka Ali juga adalah walinya". Maka menurut pendapat Ahlu Sunnah, hadits ini tidak memberikan dalil bagi wilayah kekuasaan yang berupa kepemimpinan (imamah) ataupun khilafah. Dan lafaz wilayah di dalam al- 
Qur`an tidak dipergunakan dengan pengerti an imamah atau khilafah. Bahkan yang dimaksud dengan wilayah di dalam al-Qur an adalah wilayah pertolongan dan kasih sayang, baik di antara mukmin ataupun di antara orang kafir. Maka firman Allah swt. mengenai wilayah antara kaum mukminin adalah:

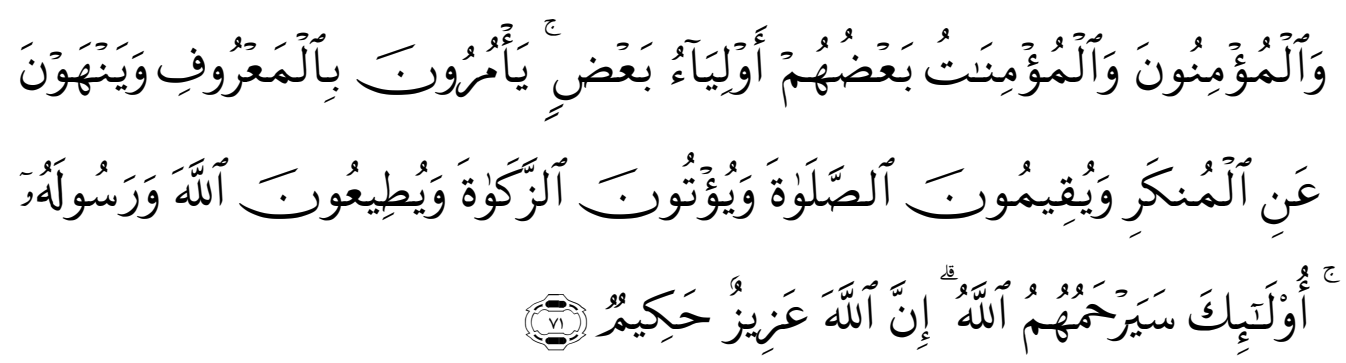

Terjemahnya:

dan orang-orang yang beriman, lelaki dan perempuan, sebahagian mereka (adalah) menjadi penolong bagi sebahagian yang lain. mereka menyuruh (mengerjakan) yang ma'ruf, mencegah dari yang munkar, mendirikan shalat, menunaikan zakat dan mereka taat pada Allah dan Rasul-Nya. mereka itu akan diberi rahmat oleh Allah; Sesungguhnya Allah Maha Perkasa lagi Maha Bijaksana. (At-Taubah: 71).

Sedangkan fi rman Allah swt mengenai wilayah antara orang-orang kafi $r$ adalah:

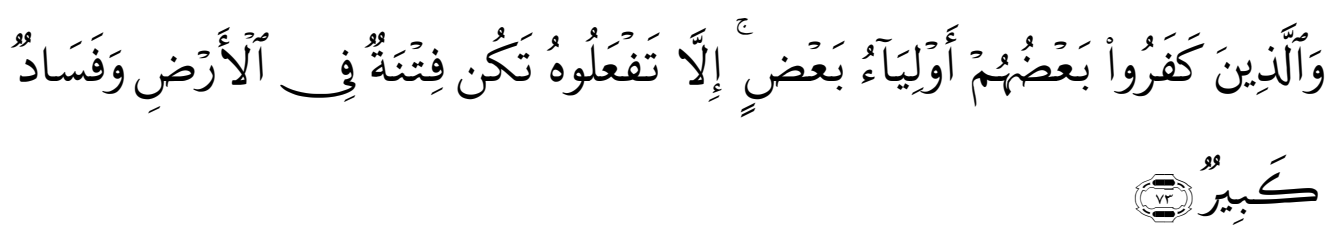

Terjemahnya:

Adapun orang-orang yang kafir, sebagian mereka menjadi pelindung bagi sebagian yang lain. jika kamu (hai Para muslimin) tidak melaksanakan apa yang telah diperintahkan Allah itu, niscaya akan terjadi kekacauan di muka bumi dan kerusakan yang besar.

Dengan demikian, makna wilayah di dalam al-Qur`an adalah orang yang menjadikan kamu sebagai penolong dan pelindungnya. Maka Ali adalah 
penolong dan pelindungnya, maksudnya, barang siapa yang menjadikan aku sebagai penolongnya dan pelindungnya, maka Ali menjadi penolong dan pelindungnya. Jadi maknanya: sesungguhnya Ali mengikuti langkah Nabi saw. Jadi dia tolong orang yang menolong Nabi saw, dan orang yang menolong Nabi saw hendaknya menolongnya juga. Dan ini adalah suatu keisti mewaan yang besar. Ali ra telah menolong Abu Bakar, Umar, dan Utsman, serta dia lindungi mereka.

Jadi hadits Nabi saw ini tidak menjadi hujjah atau bantahan kepada Ahli Sunnah, bahkan menjadi hujjah bantahan kepada Syiah, sebab hadits ini tidak memberikan indikasi mengenai kepemimpinan "imamah". Bahkan ia mengindikasikan pembelaan darinya baik dalam keadaan sebagai imam ataupun sebagai makmum. Jika hadits ini memberikan indikasi kepemimpinan ketika ia diucapkan, maka Ali menjadi imam keti ka masih ada Nabi saw., dan tidak ada seorangpun yang berpendapat seperti ini.

Masalah sifat ma'shum bagi Syiah memiliki ikatan yang kuat dengan masalah kepemimpinan politik (imamah). Dan sifat ma'shum bagi mereka adalah salah satu permasalahan agama yang paling penting dan utama. Karena menurut pandangan mereka sifat ma'shum adalah syarat utama dalam imamah, sehingga menjadi sifat yang paling menentukan dalam imamah. Ini adalah pandangan Syiah Imamiah dan Syiah Isma'iliyah.

Sedangkan Syiah Zaidiyah tidak sependapat dengan mereka dalam permasalahan sifat ma'shum. Di antara mereka ada yang berpendapat bahwa yang memiliki sifat ma'shum hanyalah ahli al-kisaa`saja (Nabi saw, Ali bin Abi Thalib, Fathimah, Hasan, dan Husein). Dan di antara mereka ada yang berpendapat bahwa hanya Imam Ali saja yang memiliki sifat ma'shum. Dan di antara mereka ada yang menafi kan sama sekali sifat ma'shum dari imam. Dan ada juga berpendapat sama dengan Syiah Imamiyah dan Syiah Isma’iliyah bahwa semua imam adalah ma'shum.

Meskipun ada perselisihan di antara mereka mengenai sifat ma'shum imam, namun setelah meneliti secara mendalam dari berbagai sumber rujukan yang ada, boleh disimpulkan bahwa mayoritas ulama Syiah Zaidiyah ti dak mengakui sifat ma'shum para imam. Oleh karena itu, para ulama Syiah Zaidiyah membantah dan mengkritik Syiah Imamiyah dan Syiah Isma'iliyah dalam permasalahan ini.

Yang perlu diberikan perhati an secara seksama di sini adalah kritikan Syiah Zaidiyah terhadap Syiah Imamiyah dan Syiah Isma'iliyah Bathiniyah dalam masalah ini, yaitu ungkapan para ulama Syiah Zaidiyah bahwa tidak ada di dalam 
al-Qur`an, hadits, ijma', ataupun dalil akal yang menunjukkan adanya sifat ma'shum orang yang mereka klaim sebagai imam. Bahkan para nabi terkadang melakukan kesalahan dalam beberapa keadaan sebagaimana halnya manusia yang lain. Lalu mereka bertaubat dari kesalahan mereka. Dan seperti inilah keadaan para nabi, oleh karena itu dipertanyakan tentang bagaimana halnya dengan para imam yang ti dak dapat mencapai derajat kenabian?.

terhadap Syiah dalam teori sifat ma'shum imam, maka dapat dilihat bahwa sifat ma'shum hanya milik Nabi saw. saja. Dan umat islam telah sepakat mengenai sifat ma'shum para nabi dan rasul dalam menyampaikan risalah dari Allah. Dan mereka melihat bahwa pendapat Syiah mengenai sifat ma'shum para imam tidak dapat diterima. Sesungguhnya orang yang ma'shum wajib untuk diikuti pada semua yang dia katakan, dan tidak boleh melanggarnya. Dan ini adalah sifat keisti mewaan untuk para nabi. Oleh karena itu kita diperintahkan untuk beriman dengan apa yang diturunkan kepada para Nabi.

Di sisi lain, Ahlu Sunnah menegaskan bahwa Ali, Hasan, dan Husein, serta keturunan keduanya ti dak pernah mengklaim diri mereka memiliki sifat ma'shum dan suci dari kesalahan dan dosa. Bahkan mereka mengakui berbagai dosa mereka secara rahasia dan terang-terangan. Dan mereka memohon ampunan kepada Allah dengan penuh kekhusyu'an dan ikhlas.

Respon dan kriti kan Ahlu Sunnah terhadap pendapat Syiah bahwa imamah merupakan salah satu rukun agama. Dan Ahlu Sunnah telah menjelaskan bahwa imamah bukanlah salah satu rukun atau dasar agama. Dan ia hanyalah salah satu furu' (cabang) agama, yang ti ada kena mengena dengan akidah keimanan. Menurut pendapat Ahlu Sunnah, Islam terdiri dari lima rukun utama, yang dipercayai oleh semua orang Islam dan dipraktikkan, sehingga seseorang dapat dianggap sebagai seorang Islam. Urgensi terkumpulnya kelima rukun Islam dalam mengindentifi kasi seseorang sebagai seorang Muslim nampak jelas terlihat dalam hadits Nabi saw, dari Abu Abdurrahman Abdullah bin Umar bin al-Khaththab, yang teksnya adalah:

"Aku mendengar Rasulullah saw. bersabda: Islam dibina berdasarkan lima perkara: syahadat bahwasanya tidak ada tuhan selain Allah, dan bahwa Muhammad adalah utusan Allah, mendirikan shalat, mengeluarkan zakat, melakukan ibadah haji di baitullah, dan melakukan puasa di bulan ramadhan". Diriwiyatkan oleh Bukhari dan Muslim.

Ahlu Sunnah membangun pandangan mereka mengenai rukun Islam berdasarkan hadits ini. Di mana Rasulullah saw tidak menyebutkan perkara kepemimpinan (imamah) di dalamnya. Sebagaimana tidak nampak keperluan 
kaum muslimin terhadap imamah pada masa beliau masih hidup, karena beliau adalah imam kaum muslimin.

Bagi Ahlu Sunnah orang-orang mukmin yang hidup sezaman dan menemani Nabi saw adalah manusia yang paling mulia walaupun mereka tidak memeluk akidah imamah. Karena keimanan yang benar yang telah dijelaskan oleh Rasulullah saw. adalah akidah mengakui ke-Esaan Allah, kenabian rasulullah saw., keimanan terhadap malaikat, al-Qur`an, para rasul, dan kebangkitan setelah kematian, yang diikuti dengan mendirikan shalat, dan melakukan semua jenis ibadah dan kewajiban. Dan Ahlu Sunnah juga berpandangan bahwa jika kita andaikan bahwa imamah adalah salah satu masalah agama yang paling penting, maka alangkah baiknya jika al-Qur`an menjelaskannya, dan Nabi saw. menampakkannya.

\section{DAFTAR PUSTAKA}

Abdullah bin Muhammad Hamiduddin, az-Zaydiyah, hal 122.

Abu al-Qasim Muhammad al-Hautsi, al-Mau’izhah alHasnah, hal: 104.

Muhammad bin Hasan ad-Daylami, Qawa'id 'Aqaaid Aali Muhammad, hal: 49.

Abu Zuhra, al-Imam Zaid, 484-485, Darul Fikri Arabi, Kairo, tanpa tahun.

ad-Da'i Abu Ya'qub as-Sajastani, Kitab al-Iqti shar, hal 68. Nasywan al-Humairi, Syarh Risalah al-Hur al-'Ain, hal 157.

ad-Da’i Idris Imaduddin, Kitab Zahrul Ma’ani, hal 155.

Ahmad bin al-Hasan ar-Rashshash, al-Khilafah an-Nafi 'ah, hal 224.

Ahmad bin Yahya al-Murtadha, ad-Durr al-Fara `id, waraqah 194, Ba` jim jilid

Ahmad Bin Yahya al-Murtadha, al-Bahr al-Zahhar, 1/32, Darul Kutub Ilmiah, Beirut-Lebanon, 2001.

Al- Naubakhti, Firaq Al Syi'ah, 41-42.

Al-Asy'ari, Maqalatu al-Islamiyyin, hal 2.

Al-Azhari, Tahzibullughah, 1/204.

Al-Baghdadi, al-Farq Baina alFiraq, 25, Darul Afaq al-Jadidah, Beirut-Lebanon, 1997.

Al-Asy'ari, Maqalat al-Islamiyyin, 65, Dar Ihya at-Turats al-'Arabi, BeirutLebanon, tanpa tahun. 
Al-Ghazali, al-Iqti shad Fi alI'ti qad, hal 134, cet Shubaih, Kairo.

Al-Hurr al-Amili, al-Fusul al-Muhimmah fi Usul al-Aimmah, 80-81. Al-Sayyid Abdullah Syiber, Haqqul Yaqin fi Ma'rifah Usuliddin, 106.

Al-Iji, Kitab al-Mawaqif, 3/578.

Al-Jalayand, Muhammad as-Sayyid, 1981 M, Qadhiyyatu al-Khair wasy-Syarr Fi al-Fikri al-Islami, hal 338, Kairo, Mathba'ah al-Halabi.

Al-Jurjani, al-Ta’rifat, 23, Darul Kutub al-Arabi, Beirut-Lebanon, 1405 H.

Al-Juwaini, al-Irsyad, hal 10, cet Kairo, 1950 M.

Al-Kulaini, Ushul al-Kaafi , 2/42.

al-Mashadir az-Zaidiyyah, al-Qasim ar-Rassi, Tatsbit al-Imamah, hal 55.

al-Mufi d, Awail al-Maqalat, 1364.

Al-Qadhi an-Nu'man, Da'aim al-Islam, 1/37-38. ad-Da'i Ali Bin Walid, Damighu al-Bathil, 2/18. ad-Da'i Idris 'Imaduddin, Kitab Zahru alMa'ani, hal: 183.

Al-Qurtubi, al-Jami’ li-Ahkam alQur`an, 1/184.

Al-Sayyid Abdullah Syibr, Haqqul Yaqin fi Ma'rifat Ushul al-Din, 564-570. Mu'assah al-'Alamy, Beirut, 1997.

Al-Zabidi, Taajul 'Arus, 5/405. AlShekh al-Mufi d, Awaail al-Maqaalat, 33. AlShahrastani, al-Milal wa an-Nihal, 166.

an-Naubakhti, Firaq asy-Syi'ah, hal 29.

Ash-Shahib bin Ubbad, az-Zaydiyah, hal 185.

Asy-Syahrastani, al-Milal wan-Nihal, 1/24.

asy-Syaukani, al-Badru at-Taali', 2/135.

Ibnu Hisyam, 6/82, Darul Jail Beirut-Lebanon, $1411 \mathrm{H}$.

Ibnu Khaldun, al-Muqaddimah, hal 19.

Ja'far Subhani, al-Aqidah al-Islamiah fi Madrasah Ahlil Bait, 102, 420.

Kamaluddin Nurdin Marjuni, alFiraq as-Syi'iayyah Wa Ushuluha as-Siyasiyah, hal: 3. Universiti Sains Islam Malaysia. 2009.

Kamaluddin Nurdin Marjuni, Nash'at al-Firaq wa Tafarruquha, 121, Lebanon- 
TRANSFORMASI: Jurnal Kepemimpinan Dan Pendidikan Islam

Volume: 3 Nomor 2 Juni 2020

Rekognisi Kebijakan Pemerintah Terbadap Pesantren ...., H. 28-41

Muh. Mustakim

Beirut, Darul Kutub Ilmiah, 2011.

Kamaluddin Nurdin, Imam Mahdi -Kajian Perbandingan Sunni \& Syiah-, Pts, Malaysia, 2016.

Lihat rujukan berikut: Al- Naubakhti, Firaq Al Syi'ah, 44. Al Baghdadi, Al Farq

Baina Al Firaq, 234. Kamaluddin Nurdin Marjuni, al Firaq al-Syi'iyyah wa Ushuluha al Siyaasiyyah. 7-9.

Musa al-Masawiy, asy-Syi'ah wat-Tasyayyu', hal 70.

Nisywan al-Humyari, Syarh Risalah al-Hur al-'Ain, hal 212. 